\title{
内耳液グルコースに関する研究
}

牧本一男*

目次

序論

(I) 内耳液採取方法

外リンパの採取

内リンパの採取

〔II〕内耳液グルコースの定性

1）実験方法

ペーパークロマトグラフィー ガスクロマトグラフィー

2) 実験結果

ペーパークロマトグラフィーによる成

績

ガスクロマトグラフィーによる成績

3）考按
〔III〕内耳液グルコースの定量

1）実験方法

グルコスタット法による定量

アンスロン法による定量

ソモギィ・ネルソン法による定量

2）実験結果

3）考按

〔IV〕内耳液グルコース濃度の死後変化

1）実験方法

2）実験結果

3) 考按

〔V〕綜括および考按

結、語

序論

内耳液は末梢聴覚機構を考学る時, 音振動の媒体として重要な意義を有する一方，蝸牛の代射機 構の面でも重要な立場を占める。蝸牛に関する生化学的研究は，聴覚受容装置の第一線にある毛細 胞を中心にして展開されるのが本筋である。 この毛細胞は一部は支持細胞により支えられている が，細胞の殆ど全表面はコルチ氏トンネル中のリンパに浸漬しており，毛細胞内外の物質交換はて の Corti-lymph と細胞膜との間で逐行されているものと一般に看做されている， かかる意味で内 耳液化学物質の組成を明らかにすることは，乙と数年来耳科学においての最も関心の的となつてい る.内耳液は, 独特の複雑な解剖学的構造を有する内耳の中に在り, 且つ四周を緻密な骨性迷路に より囲䌐されておるので，内耳液の採取は仲々難しく，また得られる試料も超微量である。かかる 研究技術面の障壁が今なお完全に克服されないため，研究成果も牛歩漫々の感があつた。現在迄に

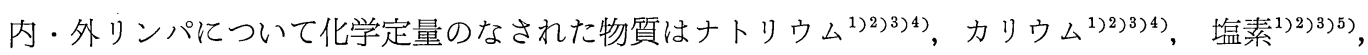

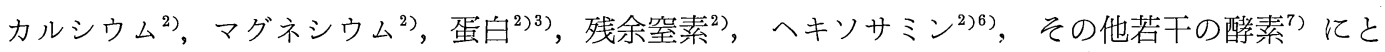
ぞまり，残余の物質については未だ確実な定量法が開発されてない。本篇記載の研究の中核である 内耳液グルコースの定性, 定量は, 広視野に立つて, 内耳物質代謝をグルコースの面から究明せん との第一着手である。

カナマイシンが細菌の好気的解糖反応を阻害する事実が解明されて以来, カナマイシン難聴に関 する実験的研究面でも内耳の糖代謝を迴つて研究がなされて来た。その結果，蝸牛においては毛細 胞, 血管条, 外ラセン溝等に Cytochrome-oxidase ${ }^{8)}$, Succinate-dehydrogenase ${ }^{8)}$, DPNH-diaphorase $^{9) 10)}$, TPNH-diaphorase ${ }^{910)}$ の強い活性が証明され，他方カナマイシン中毒動物では外毛 細胞の Cytochrome-oxidase ${ }^{11)}$, Succinate-dehydrogenase ${ }^{1112)}$ ，および DPNH-diaphorase ${ }^{12)} の$

* 京都大学耳鼻咽喉科学教室（主任：森本正紀教授） 
活性が特異的に低下することが明らかとなり，蝸牛外毛細胞で営まれておるての活発な好気的代 謝が，外毛細胞の聴覚生理において重要な 役割を果しておるとの見解が有力となつて来た。一方 Koide $~^{13)}$ は， 迷路動脈を切断すると外リンパのグルコース濃度が急速に低下することを観察し， 蝸年軟部組織における解糖は比較的娧気的条件下でも進行し得ることを示唆した。 Vosteen ${ }^{8}$ によ ると, Cytochrome-oxidase と Succinate-dehydrogenase は毛細胞に比し血管条でややその活性 が高いが，Lactate-dehydrogenase は逆に血管条で活性が極めて低く，毛細胞において比較的高い とされている.乙の所見より，毛細胞内の解糖が嫌気的条件下でも進行し得ると推論された。

毛細胞のみならず，内耳液の分泌・吸収にとり重要な部位と知られる血管条および外ラセン溝に ついても，従来その糖代謝について研究がなされて来た。しかしその研究方法は組織化学的方法に 限られており，解糖系の基質であるグルコースについてその消長を内耳液において動的に観察した 研究は従来てれをみない：著者はかかる実験を可能にするために，内耳液グルコースの定性・定量 についてその微量化学的方法を確立するてとをもつて本研究の主目的とした。血液・内耳液間のグ ルコースの移行状態やグルコースの内耳での回転率を研究するには，将来放射性グルコースによる 追跡実験が駆使されると予想され，乙てにおいて当然内耳液中の放射性グルコースの同定という仕 事が必要に迫られて来る。乙の必要性に鑑み，著者は内耳液グルコースの定性法に関して検討を行 ないペーパークロマトグラフィー，ガスクロマトグラフィーの 2 方法についてその検出条件等を吟 味した。

内耳液グルコースの定量に際して問題になるのは，外リンパは $10 \mathrm{mg}$ 前後の液量が採取されるの に対し，内リンパの採取液量は $1 \mathrm{mg}$ 前後に過ぎないてとである．従つて内リンパの定量に当つて は外リンパの定量法を更に微小化する必要があり，著者は外リンパの定量は通常の $3 \mathrm{ml}$ 液漕によ る光電比色法をもつて行ない，内リンパの定量には $0.2 \mathrm{ml}$ ミクロセルによる方法を適用すべく試み た.グルコースの定量法としては，数多くの定量法の中より原理的に異なる次の 3 方法を採用して みた. 即ち，1）D-グルコースに特異的反応をなす Glucose-oxidase による方法（グルコスタッ 卜法），2）ヘキソース一般に呈色反応を来たすアンスロンによる方法（アンスロン法），3）糖質の 還元性を利用したソモギィ・ネルソン法である。 ての 3 方法をもつてモルモットの内耳液について グルコース濃度を測定し，先ずその正常值を求め，更に固体間変動についても検討を加えた。 また ミクロセルを利用して内リンパグルコース濃度を測定する場合には，実験誤差の問題についても考 察をなした。

内耳液の化学定量に当つては液採取時の血液混入が常に問題となる。この血液混入を避けるため に動物を断頭，捨血したのち内耳液採取を行なう研究者もある。乙の方法は実験の目的によつては 有用な方法といえる．著者は，死後の内耳液がグルコース定量の場合にも果して生理的条件下のも のに代理し得るか否かを検討するため，動物の死後，内・外リンパを採取しグルコース濃度の推移 を経時的に観察してみた。

蝸牛には音刺激に対して交流電気反応を示す Cochlear Microphonics (CM) の存するととは今 日周知である．乙の反応は個体の死後もなお微小ながら存続する $\left.(\mathrm{CM} 2)^{14}\right)$ が，乙の本態について はてれを蝸牛の生活反応とみるか，或いは機械的現象とみるかの二つの見解が対立し今なお論議が 続いておる．惟うに， CM2 が真に蝸牛組織の生活反応であるとすれば，蝸牛毛細胞は内耳液より グルコースを摂取し嫌気的解糖をもつて CM2 の産生を支えている可能性がある。加様な想定の下 に, 本研究の附随的問題として死後の内耳液グルコース濃度の観察に併行して CM voltage の死後 推移を記録観察し，死後のグルコース消費について若干の機能的解析をなさんと試みた。 


\section{〔I 内耳液採取法}

外リンパ採取に比して内リンパ採取は格段に困難で あるので，両者を同一耳より採取するととは断念し， 内・外りンパの何れか一つのみ採取するととに精神を 集中した．実験動物は全てモルモットである．

外リンパの採取：動物をネンブタール麻酔下（3 $\mathrm{mg} / 100 \mathrm{~g}$ ）に仰臥位に固定し, 前外側より中耳骨胞に 達し，乙れを開放して正円空を30倍の実体顕微鏡視野 の中心に求めるようにする.内経約 $1 \mathrm{~mm}$, 長さ 6 〜 $7 \mathrm{~cm}$ の硬質ガラス毛細管の尖端を細くしたものを採 取管とし，乙れを電極マニプレーターで把持し，実体 顕微鏡下で管の尖端を正円空膜に刺入する。管に連結 されたビニール管を口にあて緩やかな一定の吸引を加 えると，液は一定の速度で管を上昇し， ある点に達す ると止む。ととで更に吸引するととなく採液を終る。 外リンパ採取に当つては正円空膜以外の部位, 特に基 底板に損傷を加えぬよう常にガラス毛細管の刺入方向 と刺入の深さに注意を払つた.

内リンパの採取：外リンパ採取の場合と同様に麻 酔，固定し，先ず正円空膜と鐙骨底を除去し，スポン ゼル，濾紙等の小片を使用して鼓室階，前庭階の両外 リンパを全部吸いとる，仰卧位に固定された動物を術 側耳が上方にくるよう固定を変え，第 1 図の如く正円 空をひさし状におうた骨壁を削除すると実体顕微鏡下
第 1 図

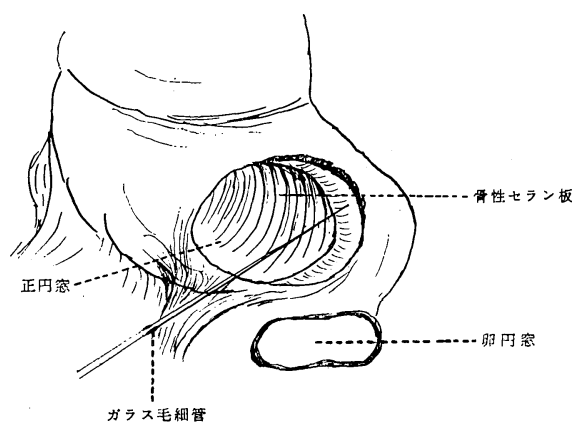

に骨性ラセン板が現われる，骨性ラセン板の外側に帯 状に見えるのが基底板であり，顕微鏡の拡大率を40〜 50倍にして，ての部より蝸牛管内にガラス毛細管を刺 入する. ガラス毛細管は微小電極用のものを使用し, 尖端外径を 10〜20 $\mu$ 大に作製したものである. 毛細管 に加える吸引は外リンパ採取の場合と同様, 連結ビニ ール管を介して吸引するが，それを極めて微弱に行な つた.

液の採取は原則として両耳について行ない，血液混 入の認められた液は全て本研究の陚料より除外するこ ととした。

\section{〔II〕内耳液グルコースの定性}

ペーパークロマトグラフィーおよびガスクロマト グラフィーにより, 内耳液グルコースをより簡単によ り確実に検出, 同定する方法を見出すべく, 種々の検 出条件について哈味した. 各種検出条件のうちとくに 除蛋白法に検討を加え, また検出に要する最小内耳液 量についても吟味した。

\section{1) 実験方法}

ペーパークロマトグラフィー：外リンパに含まれる グルコースの検出を下記の $(\mathrm{a})$ ( $\mathrm{e})$ の実験条件について 吟味した。濾紙は東洋濾紙 No. 50 を使用し，発色試薬 としてはアニリンフタル酸溶液*を用いた。

(a) 液採取 ( 1 耳, 2 耳, 3 耳) $\rightarrow$ 上方展開（フェ） 一ル) $\rightarrow$ 発色

(b) " ( 2 耳) $\rightarrow$ 上方展開 (ブタ・酢・水 $) \rightarrow$ 発色

(c) " (6耳) $\rightarrow$ 除蛋白 (透析) $\rightarrow$ 上方展開（ブタ

・酢・水) $\rightarrow$ 発色 (d) 液採取 $(6$ 耳) $\rightarrow$ 除蛋白 (トリクロル酢酸 $) \rightarrow$ 上方 展開 (ブタ・酢・水) $\rightarrow$ 発色

(e) " ( 5 耳) $\rightarrow$ 除蛋白（トリクロル酢酸 $) \rightarrow$ 下方 展開 (ブタ・酢・水) $\rightarrow$ 発色

(a)は検出に要する最小内耳液量に見当をつけるため の実験で，外リンパの平均採取量 $(6 \sim 8 \mu l)$ の 1 耳分 のみを検体とした場合， 2 耳分集めた場合，3耳分集め た場合，てれら 3 条件について水飽和フェノールを展 開溶媒とし上昇法の展開を行なつたものである。(b)は 上記実験で，検体を 2 耳分としブタ・酢・水の展開溶 媒**を使用した場合の実験である。(c)および(d)は被検 液の除蛋白について，その必要性または方法の優劣を 吟味するための実験であり，先ず(c)では透析法による 除蛋白を実施した．即ち cellulose tubing 内に試料を 入れ， 12 時間透析を行なつた後その外液を除蛋白濾液 として採取した．(d)では透析法に代えてトリクロル酢

* $0.93 \mathrm{~g}$ のアニリンと $1.6 \mathrm{~g}$ のフタル酸を $100 \mathrm{ml}$ の水飽和ブタノールに溶解し調製したもの ${ }^{15)}$

**ブタノール, 酢酸, 水を $4: 1: 2$ (体積比)に混合したもの 
酸法 ${ }^{16}$ による除蛋白を行なつた，液の配合は試料 1 容 に対し $10 \mathrm{~g} / \mathrm{d} 1$ トリクロル酰酸 9 容とし, 以後遠沈 $(2000$ r.p.m., 10分）を行ない上澄液を除蛋白濾液として採取 した。(e)は上記(d)の場合を下降法で行なつた実験であ る.

ガスクロマトグラフィー：試料採取よりガスクロマ トグラフへの導入に至る 実験手順は 以下の如くであ る。陚料採取 (外リンパ, 脳脊髄液, 血液) $\rightarrow$ 除蛋白 $\rightarrow$ 凍結乾燥 $\rightarrow$ Trimethylsilyl 化 (TMS 化) $\rightarrow$ ガスク ロマトグラフィー．外リンパは 6 耳分 (約 $50 \mu l$ )を集 め 1 検体とし, 脳脊髄液, 血清は 1 匹の動物より $50 \mu l$ を 採取しそれぞれ 1 検体とした。脳背髄液は後頭下穿刺 により採取し，血清は股静脈より採血した。除蛋白は 水酸化亜鉛法, トリクロル酢酸法および透析法の 3 方 法で行ない，トリクロル酢酸法および透析法はペーパ 一クロマトグラフィーにおけると同様に行ない，水酸 化亜鉛法は以下の如く ${ }^{17}$ ) 行なつた。即ち試料 1 容に対 して $0.45 \mathrm{~g} / \mathrm{dl} \mathrm{ZnSO} \mathrm{Zn}_{4} \cdot \mathrm{H}_{2} \mathrm{O}$ 溶液 32 容と $1 / 10 \mathrm{~N} \mathrm{NaOH}$ 溶 液 7 容を加光試料の 40 倍溶液とし, 次いで遠沈 $(2000$ r.p.m., 10分)を行ない生じた上澄液を採取する.TMS 化は Sweeley らの方法 ${ }^{18}$ 亿準じ以下の如く行なつた.

(1) 凍結乾燥した試料をピリジン $1 \mathrm{ml}$ 亿溶解する.

(2) 上記溶液に Hexamethyldisilazane $0.2 \mathrm{ml}$, Trimethylchlorsilane $0.1 \mathrm{ml}$ 加える.

(3) 上記混合液を 5 分間加熱 $\left(60 \sim 70^{\circ} \mathrm{C}\right)$ する.

（4）加熱終了後溶液を冷却し，乙れにクロロホルム $3 \mathrm{ml}$, 水 $3 \mathrm{ml}$ を加え 1 分間静置した後その上 清のクロロホルム層を採取する。
男

耳鼻臨床 $60: 9$
（5）採取した液を減圧蒸溜し約 $10 \mu l$ 迄濃縮する.

（6）上記濃縮液をマイクロシリンジで $3 \mu l$ 取りガス クロマトグラフへ導入する.

以上は凍結乾燥した試料を直接 TMS 化した場合で あるが，一方 TMS 化の前段階で試料のメチル化を行 なつた場合についてもガスクロマトグラフィーを試み た. このメチル化はグルコースを Methyl $\alpha$-Glucopyranoside に変化させる目的であり，乙のためには 19)武料に 3\%×タノール塩酸を加え，てれを封管内で $100^{\circ} \mathrm{C}, 3$ 時間加熱した.

ガスクロマトグラフはイオン化検出器を用いた島津 製作所製 GU-21R を使用した。 カラム充鎮㓮は，担 体として Chromosorb W(HMDS $\left.)^{19}\right)$ を, 固定相液体 として $5 \%$ Ucon L B 550X $\left.{ }^{19}\right)$ を用いた。 カラム温度 は186〜 $193^{\circ} \mathrm{C}$ 間においた。 キャリャーガスとしては アルゴンガスを使用し，流速は $10 \mathrm{ml} / 11 \mathrm{sec}$. 10ml $/ 14$ sec.の間とした。

\section{2) 実験結果}

ペーパークロマトグラフィー: 第 2 図の右側に示し たペーパークロマトグラムは試料の除蛋白を行なわな かつた場合の結果であり,外リンパ, 標準グルコース溶 液および両者の混合液の 3 者をフェノールで展開（上 昇法) し，アニリンフタル酸で検出したものである. 図示の如く 3 者の間には Rf 值 (0.39) 亿殆ど差がみ られず，またブタ・酢・水で展開した場合にも Rf 值 （0.18）には 3 者間に差を認めなかつた。これより, 外リンパのグルコースについてペーパークロマトグラ フィーを行なうに当つては, 上記方法で行なう場合に

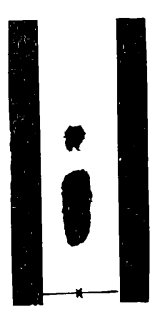

モルモット外リンパ トリクロル酢酸処理 下降法

発色試薬 : アニリンフタル酸 展開溶液 :

ブタ.酢. 水. $(4: 1: 2)$

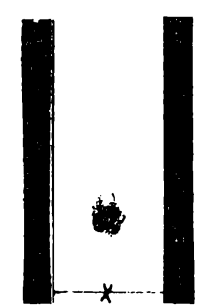

モルモット外リンパ 透析 上昇法

発色試薬 : アニリンフタル酸 展開溶液 :

ブタ.酢. 水. $(4: 1: 2)$

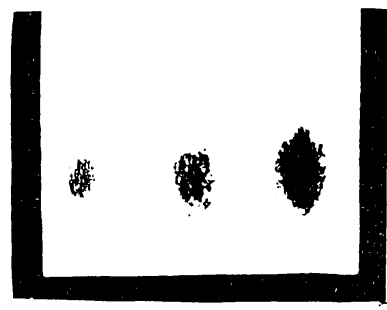

2

1 モルモット外リンパ

2 混合液 $(1+3)$

3 標準グルコース

上昇法

発色試薬 : アニリンフタル酸 展開溶液 : フエノール 
限り除蛋白の前処理を省略し得ることが明らかとなつ た.なお図に示したのは外リンパ 2 耳分 $($ 約 $15 \mu l)$ につ いてのものであるが，乙の他 3 耳分 (約 $20 \mu l) 1$ 耳分 (約 $7 \mu l$ ) についても検討したところ， 3 耳分の場合 は検出可能であつたととは勿論であるが，1 Ff分の場 合は明瞭なスポットが得られなかつた。

第 2 図中央のクロマトグラムは外リンパ 6 耳分（約 $50 \mu l)$ を透析法で除蛋白したものについて，凍結乾燥 した後ブタ・酢・水で展開(上昇法)してアニリンフタ ル酸で発色させたものである．との場合も第 2 図右側 のクロマトグラムと同様にグルコース以外の糖は検出 されていない．またての場合は外リンパを透析してい るために，その操作中に試料の損失があつて図の如く 外リンパ 6 耳分に相当する発色度は得られていない.
第 2 図左側のクロマトグラムは，外リンパ 6 耳分 （約 $50 \mu l ）$ をトリクロル酢酸法で除蛋白したものにつ いて，凍結乾燥の後ブタ・酢・水で展開 (下降法) し， アニリンフタル酸で発色させたものである．図示の如 く，スポットが上下 2 個所に認められ，上方のものが $\mathrm{Rf}=0.18$ でグルコースの位置に相当するものである. 下方のスポットが如何なる物質に相当するかについて は，その物質の同定は不可能であつたが，トリクロル 酢酸により外リンパ中のグルコースが他物質に変化し たととも考えられる．同様の結果は上昇法で行なつた 場合にも同様の結果となつた。 かくして内耳液グルコ 一スの検出に当つては，試料をトリクロル酢酸で除蛋 白するととは適当でないと結論された。

ガスクロマトグラフィー：第 3 図は標準単糖類につ

第 3 図

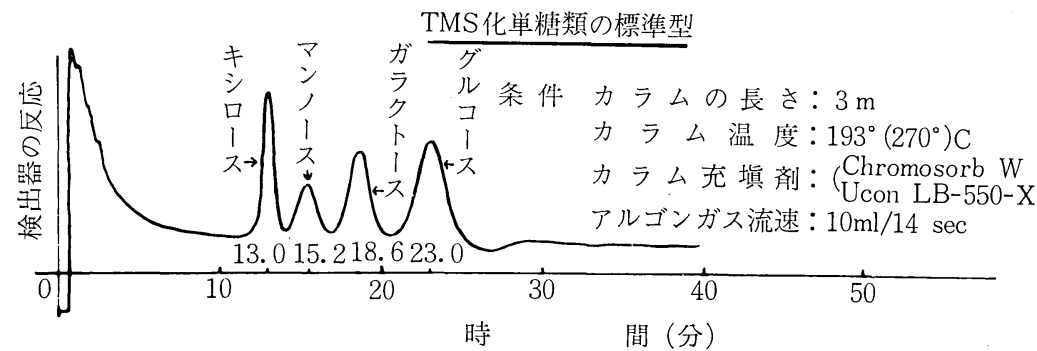

第 4 図

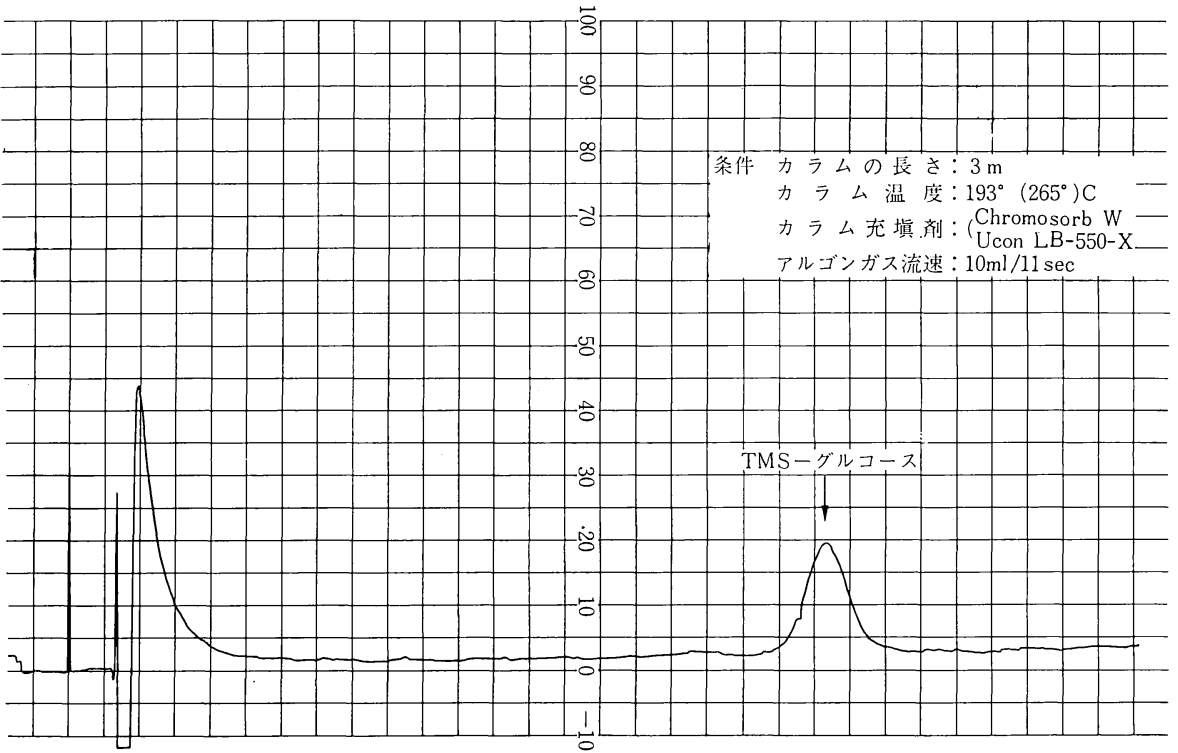


いての結果で，図に附記の検出条件で行なつた場合， グルコースの保持時間は 23.0 分, ガラクトース，マン ノース，キシロースのそれはそれぞれ18.6分, 15.2分, 13.0分であつた。水酸化亜鉛法により除蛋白した 6 耳 分（約 $50 \mu l ）$ の外リンパ試料について行なつた成績は 第 4 図の如くで，出現した唯一の波はグルコースに基 くものであるととが確認された。

トリクロル酢酸法により除蛋白した外りンパ，脳脊 髄液, 血清の各被検液について得られたガスクロマト グラムを第 5 図に示す。ての場合は 3 者何れの試料に おいても保持時間23分および35分の 2 波が出現した。 図最下段に示す如く，対照として行なつた標準グルコ 一スについての結果でも 2 波が上記の 2 点に一致して 現われ，乙れら 2 波は何れの場合もグルコースに基く ことが証明された。 か様にして, 各種体液のグルコー スについてガスクロマトグラフィーを行なう場合は, トリクロル酢酸による除蛋白法は好ましくないととを 識つた。なお血清ではグルコースの第二の波におくれ へ更に別の 1 波が観察されたが，乙れを同定すること はできなかつた。

メチル化糖については，先ず標準単糖類のガスクロ マトグラフィーを行ない第6図上段の如き結果を得た。 図示の如く, ラムノース，マンノースを除き各単糖類

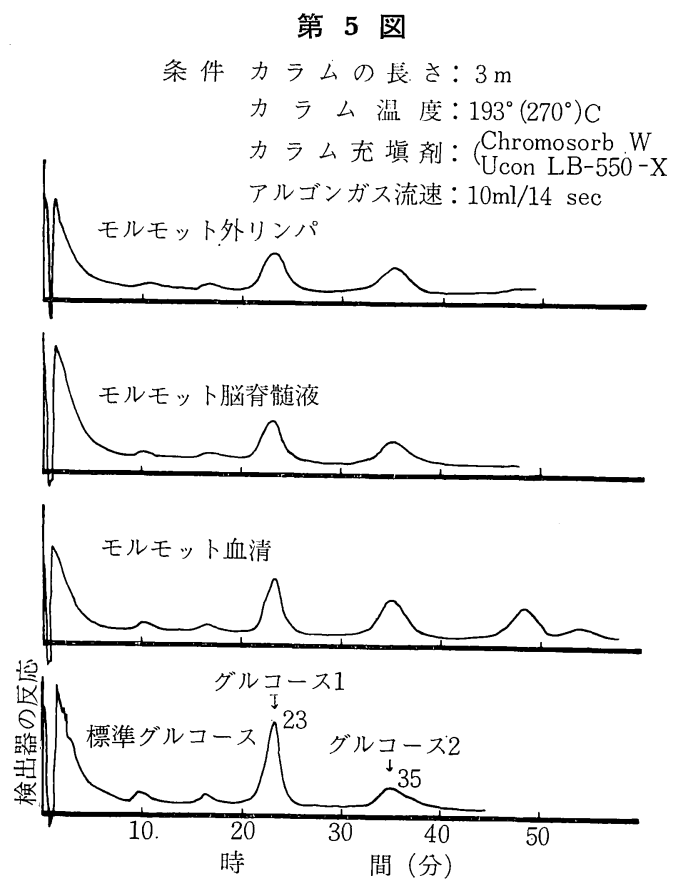

には 2 ないし 3 のピークを有する波形が見られた。保 持時間の関係はメチル化されていない場合と同じく， グルコース, ガラクトース，マンノース，キシロース

第 6 図

単糖類の標準型 (メチル化 $\rightarrow$ TMS 化)

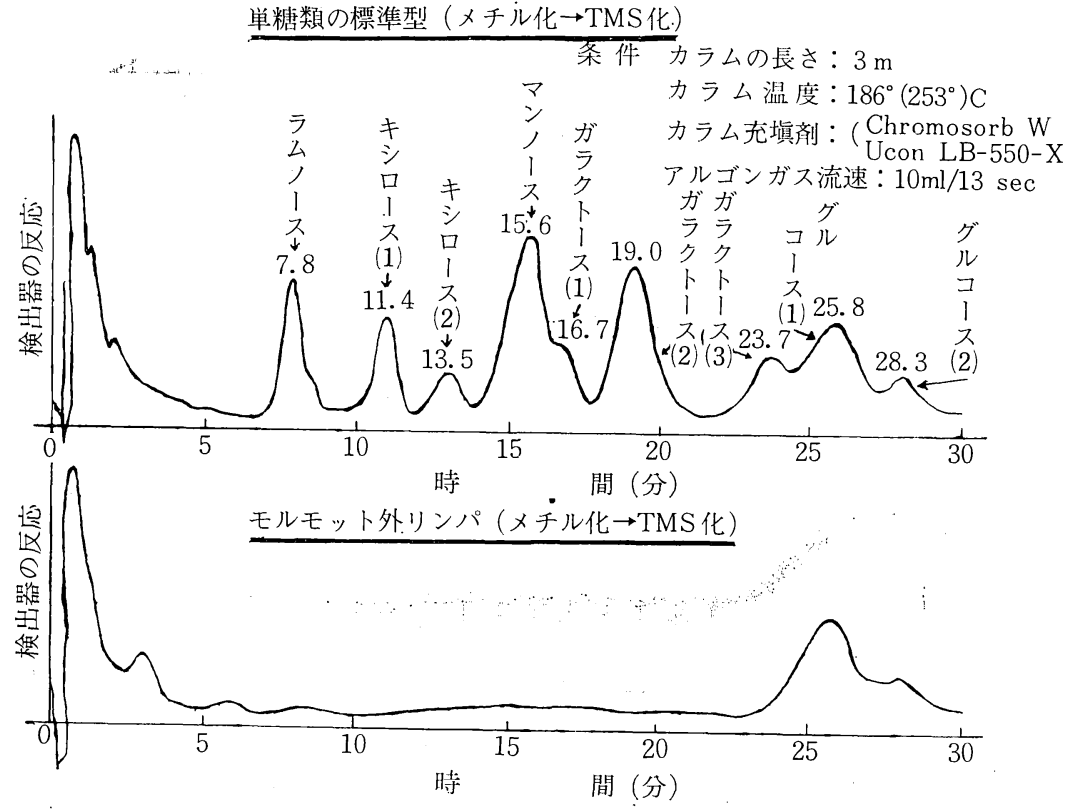


の順に短くなつている。メチル化した外リンパ試料よ り得られたガスクロマトグラムは第 6 図下段の如くで あり，出現した一つの波はその保持時間，波形とも図 上段の標準グルコースの波に一致している.

\section{3) 考按}

体液は何れも化学組成, 理化学的性状, 採液量等の 点で差暴があるので，或る物質を同一原理により検出 する場合でも全く同一の方法で操作されることは少な く，個々の体液により実施方法に何らかの修正が加え られる場合が多い。乙れは，当該の体液試料に適合し た，再現性の高い，しかも簡単で安易な方法が実際上 要求されるためである。 しかしか様な最終的な優れた 方法に到達するには，或る程度は試行錯誤法的方法に よらねばならず，或る程度は経験の累積にまたねばな らない. 糖質の化学では特にか様な要素が多いとされ ている.

体液のグルコースについてペーパークロマトグラフ ィーを行なう場合, 試料の前処理として除蛋白が問題 となるが，外リンパではこの操作を省略し得ることを 確認できた（第２図）。乙れは外リンパの蛋白濃度が 比較的低濃度 $(75 \mathrm{mg} \%)^{3}$ )であるととによると考えら れる．除蛋白操作を加えると，その間必ず試料の損失 を来たすので, 内耳液の如き超微量を対象とする化学 分析では除蛋白操作を省略し得ることは，実験遂行を 大いに有利にするものである，要するに，外リンパ武 料を直接濾紙につけ以後一般の糖のペーパークロマト グラフィー法 $\left.{ }^{20}\right)$ 亿準じて行なえば外リンパグルコース の検出は容易である.

糖類一般をペーパークロマトグラム上で検出するた めの発色試薬は 1) 酸化剂, 2) 芳香族アミン類, 3 ）フェノール類の 3 種類に大別される。酸化剂に属 するものはアンモニア性硝酸銀, 過マンガン酸カリウ ム等でありてれらは還元糖と敏感に反応し $1 \gamma$ の還元 糖を検出し得る ${ }^{15}$ ). 本実験で用いたアニリンフタル酸 は芳香族アミンに属するものであり，乙れは酸化剤に 比して還元糖に対する特異性が高く，きれいな褐色の スポットを与えてくれる ${ }^{15}$. しかし検出感度は酸化剂 に比しやや低く, 最小可検量 (還元糖) は $1 \sim 5 \gamma$ と いわれる ${ }^{15}$ )。フェノール類の発色試薬にはレゾルシ ン，ナフトレゾルシン等があり，てれらはケトヘキソ 一スに対して特異的反応を示すものである，以上の如 き各種発色試薬の一長一短を考虑すると, 外リンパグ ルコースの検出には本実験で用いたアニリンフタル酸 が最適と考えられる。
先述の如く外リンパ試料を直接濾紙につけて展開し た場合は, その 2 耳分 (約 $15 \mu l$ ) の試料についてはグ ルコースの明瞭なスポットが得られたが，1 耳分（約 $7 \mu l)$ の試料ではグルコースの検出は可能であるが, 明瞭なスポットは得られなかつた．後述の如く外リン パのグルコース濃度は平均 $125.2 \mathrm{mg} / 100 \mathrm{ml}$ であるの で，第 2 図右側のクロマトグラムにみる如き外リンパ 2 耳分 (約 $15 \mu l$ ) から得られた明瞭なスポットは約 $19 \gamma$ のグルコース量に相当する発色度を示しているこ とになる。一方内リンパについてみると，グルコース の明瞭なスポットを得るには当然 $19 \gamma$ 前後のグルコー ス含有量に相当する内リンパ液量が必要となる。内リ ンパの蛋白濃度は外リンパのそれの約 $1 / 3$ である3 $)^{3}$ ら，外リンパにおけると同様除蛋白の必要はないもの と考えられる。

糖類のガスクロマトグラフィーに関する研究は，糖 の揮発性化合物をつくることが困難であつたため進歩 が妨げられていた。 しかし1963年 Sweely らがTMS 化による糖類のガスクロマトグラフィーについて系統 的研究を行なつて以来, 糖類の化学分析に一段の発展 がみられてきた。

本研究において，グルコース，ガラクトース，マン ノース, キシロースの標準結晶試料について TMS 化 を行つた後, 第 3 図附記の如き実験条件でガスクロマ トグラフィーを行なつたところ，これらの物質はガス クロマトグラム上にキシロース, マンノース, ガラクト ース，グルコースの順にそれぞれ一つのピークをもつ て出現している．保持時間の関係はグルコースのそれ を 1.00 とすると，ガラクトース 0.81 , マンノース0.67， キシロース0.56であつた，因みに Sweely らが SE-52 のカラムを使用し, カラム温度 $140^{\circ} \mathrm{C}$ で行なつた観察に

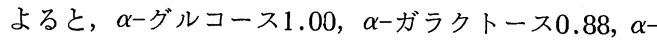
キシロース 0.43 となつており，本実験で収めた結果と 大略一致している．水酸化亜鉛法により除蛋白した外 リンパ試料のガスクロマトグラムでは, 唯一のピーク が観察されその保持時間は標準グルコースのそれに一 致していた．か様にグルコースがガスクロマトグラム 上で一つのピークをもつて現われるととは少なくとも 次の二つの事象を意味する．第一は試料中のグルコー スがピリジン溶液中で変旋光によつて異性体を生ずる 傾向が極めて低い $\left.{ }^{18}\right)$ とであり，第二は試料中グルコ 一スの有離 $\mathrm{OH}$ 基が全て TMS 化されている $\left.{ }^{18}\right) こ と$ である。

一方，試料をトリクロル酢酸で処理すると，標準試 
料および各種体液試料においてグルコースの二つのピ 一クが現われたので（第 5 図），との場合グルコース は TMS 化の前段階で $\alpha$ および $\beta$ の異性体に解離 $(\alpha$ $>\beta)$ していたことになる．TMS 化の前段階で試料 をメチル化して Methyl-Glucopyranoside へ誘導した 場合は，当然 $\alpha$ および $\beta$ の異性体が生ずるので，第 6 図の如きガスクロマトグラムを得るのは当然とい光 る. Sweely らによれば18)，グルコースの場合最初の ピークが Methyl $\alpha$-Glucoside であるという.

内耳液の如き体液について糖類を化学分析するに当 つては，一般にその異性体構造が問題となるととは少 ないと考えられるので，ガスクロマトグラフィーにお いても特別の実験目的を除いては陚料のメチル化は必 要ではない.
本実験におけるガスクロマトグラフィーでは，当初 外リンパ 6 耳分を対象としているが，最終的にガスク ロマトグラフに導入された試料は大略その $1 / 3$ ( 2 耳分 相当量) と考えてよい，従つて第 4 図のピークの面積 は外リンパ 2 耳分のグルコース量 (約 $20 \gamma$ ) 表わすも のである。これより, 実験操作中での試料の損失を可 及的に小にするととができれば，外リンパ1耳分（約 $7 \mu l)$ そついてもグルコース検出は可能となる. 内リン パについても相当液量を採取集合すれば，グルコース 検出は充分可能であると考えられる。

グルコース以外の単糖類について考えてみると，外 リンパでは第 4 図にみる如く何ら検出されていない． てれより,グルコース以外の単糖類は存しても極く低 濃度であると看做される。

\section{〔III〕内耳液グルコースの定量}

グルコースの定量法には種々の方法があるが，本研 究ではグルコスタット法, アンスロン法, ソモギィ・ ネルソン法の 3 法を採用した. グルコスタット(WORTHINGTON BIOGHEM. CO.) は Glucose-oxidase と Peroxidase を組合わせた試薬で，グルコースに特 異的な比色定量法に使用されている ${ }^{21222}$ ，その原理は 次の反応式の如くである.

$$
\begin{aligned}
& \text { グルコース }+\mathrm{O}_{2}+\mathrm{H}_{2} \mathrm{O} \stackrel{\text { Glucose-oxidase }}{\longrightarrow} \mathrm{H}_{2} \mathrm{O}_{2}+ \\
& \text { グルコン酸 } \\
& \mathrm{H}_{2} \mathrm{O}_{2}+\text { 還元クロモーゲン } \stackrel{\text { Peroxidase }}{\longrightarrow} \mathrm{H}_{2} \mathrm{O}+ \\
& \text { 酸化クロモーゲン. }
\end{aligned}
$$

即ち, 定量の対象となつているグルコースは試薬中 の Glucose-oxidase の作用でグルコン酸になり，その 際 $\mathrm{H}_{2} \mathrm{O}_{2}$ を発生する. $\mathrm{H}_{2} \mathrm{O}_{2}$ と試楽中の還元クロモー ゲンの反応を試薬中の Peroxidase が触媒し還元クロ モーゲンを酸化グロモーゲンにする，酸化クロモーゲ ンが黄色を呈するのでてれを比色定量法に利用する．

アンスロン*はヘキソース一般と広く反応し緑色を

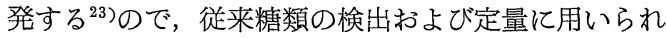
ている．乙の発色反応の機構は未だ充分明確にされて ないが，糖より Furfural またはその誘導体が形成さ<smiles>O=C1C2=C(CCCC2)C2CC=CCC12</smiles>

** Chromogen 1 管を蒸溜水 $34 \mathrm{ml}$ 亿溶解したもの

*** Glucostat 1 管を蒸溜水 $17 \mathrm{ml}$ 亿溶解したもの
れる過程が本反応に必要条件となるとされる ${ }^{24}$. アン スロン法は体液の如くグルコース以外の糖が被検液に 含まれる場合は，真のグルコース量の測定には適当で なく，むしろ全へキソース量を測定する場合の簡便法 として有意といえる。ソモギィ・ネルソン法は元来, 血液の真糖量測定法として考案されたもので, 糖の還 元性を利用しておる ${ }^{25)}$. 即ち試料俆銅試薬を加えアル カリ性の条件で加熱すると，糖により銅は還元され， 生じた西酸化銅を酸性りンモリブデン酸と反応させる 時，モリブデンの低級酸化物の膠質溶液を生じ青色の 発現をみる。

\section{1）実験方法}

グルコスタット法による定量：先ず原法をもとにし て $10 \gamma$ 前後のグルコース量を測定し得る次のような微 量定量法を考案した.

(1) $5 \mathrm{ml}$ 試験管（内径 $10 \mathrm{~mm}$ ，長さ $105 \mathrm{~mm}$ ) 一試 料 $0.01 \mathrm{ml}$, 蒸溜水 $0.19 \mathrm{ml}$ を入れ全量を $0.2 \mathrm{ml}$ と する.

（2）各管へ Chromogen 液** $1.4 \mathrm{ml}$ 加える.

（3）更に各管へ Glucostat 液*** $0.7 \mathrm{ml}$ 加え，よく 液を混和した後室温で反応させる。

(4) 正確に10分後 $4 \mathrm{~N} \mathrm{HCl} 0.1 \mathrm{ml}$ を加え反応を停 
止させる。

(5) 以上の操作を $5 \gamma / 0.2 \mathrm{ml}, 10 \gamma / 0.2 \mathrm{ml}, 20 \gamma / 0.2 \mathrm{~m} l$ のグルコース標準溶液各 $0.2 \mathrm{ml}$, および票溜水 0.2 $\mathrm{ml}$ (盲検用) についても行なう.

（6）反応液はグルコースの存在で黄色を呈するので これを $3 \mathrm{ml}$ 液漕に入れ, 光電比色計を用い $400 \mathrm{~m} \mu$ における吸光度を測定する。標準検量曲線より被 検液のグルコース量を求める.

本微量法により既知濃度のグルコース溶液について 定量を行ない, 安定した測定值が得られる迄この微量 定量手技の練習を反復し, その上外リンパ, 脳春髄液, 血清についてグルコース濃度の測定を行なつた。外り ンパの場合は試料が 1 耳分では $0.01 \mathrm{ml}$ に満たない場 合が殆どであるので両耳分を集め，それより $0.01 \mathrm{ml}$ 採液した。

内リンパの採取液量は多くの場合 $0.5 \sim 2.0 \mathrm{mg}$ の範 囲にあり，上記方法を更に微小化した定量法が要求さ れたので第 7 図の如き之クロセルを利用して, 次の方 法で定量を行なつた。

第 7 図

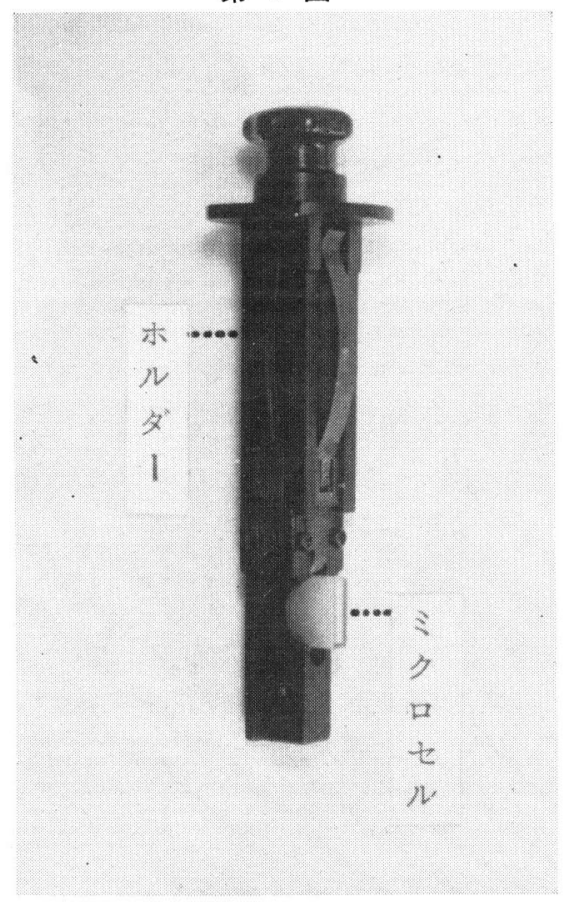

（1）内リンパ武料の重量を精秤後， $5 \mathrm{ml}$ 試験管へ 武料を入れ各管を氷室に入れ試料の乾燥をまつ.

（2）試料の乾燥後, 各管へ蒸溜水 $0.01 \mathrm{ml}$ を入れ試 料を溶解し次に Chromogen-Glucostat 混合液* $0.11 \mathrm{ml}$ を加える.

(3) 室温で正確に 10 分間反応を進行させた後 $4 \mathrm{~N}$ HCl $0.03 \mathrm{ml}$ を加え反応を停止させる.

(4) 標準検量曲線を作るため, $5 \gamma / 0.2 \mathrm{ml}, 10 \gamma / 0.2 \mathrm{ml}$, $20 \gamma / 0.2 \mathrm{ml}$ のグルコース標準溶液各 $0.2 \mathrm{ml}$ ，およ び蒸溜水 $0.2 \mathrm{ml}$ (盲検用) について, ChromogenGlucostat 混合液 $2.2 \mathrm{ml}$ を加え，同様にして 10 分後 $4 \mathrm{~N} \mathrm{HCl} 0.6 \mathrm{ml}$ を加气，発色液の吸光度を 次の如く測定する.

（5）発色液を $0.2 \mathrm{ml}$ ミクロセル（島津製作所製 No. 33-29-17) へ入れて $400 \mathrm{~m} \mu$ における吸光度を 測定する。得られた標準検量曲線より被検液のグ ルコース量を求める.

ミクロセルを利用する内リンパ定量法においては, その測定值が大きく変動することが予想されるの で，予め本測定法について実験䛊差を検討することに した。 即ち既知浱度のグルコース溶液 $(10 \gamma / 0.2 \mathrm{ml})$ に つい 10回測定し, 測定值（吸光度）の標準偏差を求 めた。

アンスロン法による定量：試料中の $10 \gamma$ 前後の糖量 を測定可能にするために，原法 ${ }^{26}$ ) 次の如く改変し た。

(1) $5 \mathrm{ml}$ 共栓附試験管 (内径 $10 \mathrm{~mm}$, 長さ $105 \mathrm{~mm}$ ) へ試料 $0.01 \mathrm{ml}$, 蒸溜水 $0.19 \mathrm{ml}$ を入れ全量を 0.2 $\mathrm{ml}$ とする.

（2）各管へアンスロン試薬** $2.0 \mathrm{ml}$ を加える．この 場合試験管内で熱が発生するので, 試験管を氷水 で泠却しながら操作する。

（3）管内の液を混和し煮沸水浴中で正確に16分間加 熱する。

（4）加熱後，流水で急冷する.

（5）試料にヘキソースが存すれば緑色の発色がみら れる。 その発色液を $3 \mathrm{ml}$ 液漕に入れ， $620 \mathrm{~m} \mu$ の 吸光度を測定する。

この場合標準溶液としては，グルコスタット法にお けると同じく $5 \gamma / 0.2 \mathrm{ml}, 10 \gamma / 0.2 \mathrm{ml}, 20 \gamma / 0.2 \mathrm{ml}$ のグル コース溶液各 $0.2 \mathrm{ml}$ を用い，盲検には蒸溜水 $0.2 \mathrm{ml}$

* Chromogen 1 管を $34 \mathrm{ml}$ に, Glucostat 1 管を $17 \mathrm{ml}$ にそれぞれ蒸溜水で溶解し両者を混合したもの

** $66 \% \mathrm{H}_{2} \mathrm{SO}_{4} 200 \mathrm{ml}$ にアンスロン $100 \mathrm{mg}$ ，チオウレア $2 \mathrm{mg}$ を溶解したもの 
を用いた。

本法によつて外りンパ，脳脊髄液，血清について測 定を行なつた．外リンパはグルコスタット法の場合と 同様，両耳分を集めたものより $0.01 \mathrm{ml}$ を採液してれ を 1 検体とした。

アンスロン法についても内リンパを測定するための ミクロセル法を試みたが，測定波長 $(620 \mathrm{~m} \mu)$ が赤端 に近いため, 比色計に光透過度が不足し結局ミクロセ ル法は適用できなかつた，従つて内リンパの測定に当 つては内リンパ武料を $10 \mu l$ 前後に達する迄重積して れを 1 検体とし，乙の重量を精科した後外リンパ定量 法に準してそのアンスロン值を求めた.

ソモギィ・ネルソン法による定量：0.06N Ba(OH $)_{2}$ 溶液, $1 \mathrm{~g} / \mathrm{dl} \mathrm{ZnSO}_{4}$ 溶液, 銅試薬, 呈色試薬等の調 製は原法 ${ }^{25)}$ 亿準じて行なつた. 外リンパのソモギィ・ ネルソン值についての測定は以下の如き変法をもつて 行なつた。

(1) $5 \mathrm{ml}$ 試験管 (内径 $10 \mathrm{~mm}$, 長さ $105 \mathrm{~mm}$ ) へ試 料 $0.01 \mathrm{ml}$, 蒸溜水 $0.19 \mathrm{ml}$ を入れ全量を $0.2 \mathrm{ml}$ とする. 一方 $5 \gamma / 0.2 \mathrm{ml}, 10 \gamma / 0.2 \mathrm{ml}, 20 \gamma / 0.2 \mathrm{ml}$ の グルコース標準溶液各 $0.2 \mathrm{ml}$ および蒸溜水 $0.2 \mathrm{ml}$ （盲検用）を同様の $5 \mathrm{ml}$ 試験管へ入れる.

(2) 各管へ $0.06 \mathrm{~N} \mathrm{Ba}(\mathrm{OH})_{2}$ 溶液 $0.6 \mathrm{ml}$ ずつを加え て混和し, 更に $1 \mathrm{~g} / \mathrm{dl} \mathrm{ZnSO}_{4}$ 溶液 $0.6 \mathrm{ml}$ ずつを 加光, はげしく振盪混和後遠沈する.

（3）各管から上澄液 $1.0 \mathrm{ml}$ をとり, 共栓附 $5 \mathrm{ml}$ 試
験管に入れる。

（4）各管に銅試薬 $1.0 \mathrm{ml}$ ずつを 添加後指先で管底 を軽くたたいて混和し，者沸水浴中に正確に10分 間立てておく.

（5）次いで流水で $1 \sim 2$ 分間冷却し，各管へ呈色試 薬 $1.0 \mathrm{ml}$ ずつを加え混和する。試料に還元糖が 含有されれば青色の発色がみられる。

（6）発色液を $3 \mathrm{~mJ}$ 液漕に入れ， $660 \mathrm{~m} \mu$ における吸 光度を測定し, 標準検量曲線より被検液の糖量を 求める.

本法による定量は外リンパについてのみ行なつた。 外リンパ試料の $0.01 \mathrm{ml}$ は両耳分を合わせて調達した。

全定量実験を 通じ，蒸溜水は注射用蒸溜水を 使用 し, $0.1 \mathrm{ml}$ 以下の液量の操作はマイクロピペット (PETERSEN CO.) をもつて行ない， $3 \mathrm{ml}$ 液漕は直径 $12.7 \mathrm{~mm}$ の比色用試験管を用い, 光電比色計は島津 製作所製 No. 33-29-61-64 を使用した.

\section{2). 実験結果}

内リンパ定量法（ミクロセルを利用したグルコスタ ット法変法）においては第 8 図に示したような測定値 変動がみられた。即ち，本法により $0.50 \mathrm{r} / 0.01 \mathrm{ml}$ の 標準グルコース溶液を10回繰返し測定した場合，その 測定值 (吸光度) の標準偏差は 0.031 であつた。 てれ は濃度50mg\%の内リンパ $1 \mathrm{mg}$ を被検液とした場合に は約 $10 \mathrm{mg} \% の$ 偏差に相当する. 同時に $0.25 \gamma / 0.01 \mathrm{~m} l$, $0.50 \gamma / 0.01 \mathrm{~m} l, 1.00 \gamma / 0.01 \mathrm{~m} l$ のグルコース標準溶液に

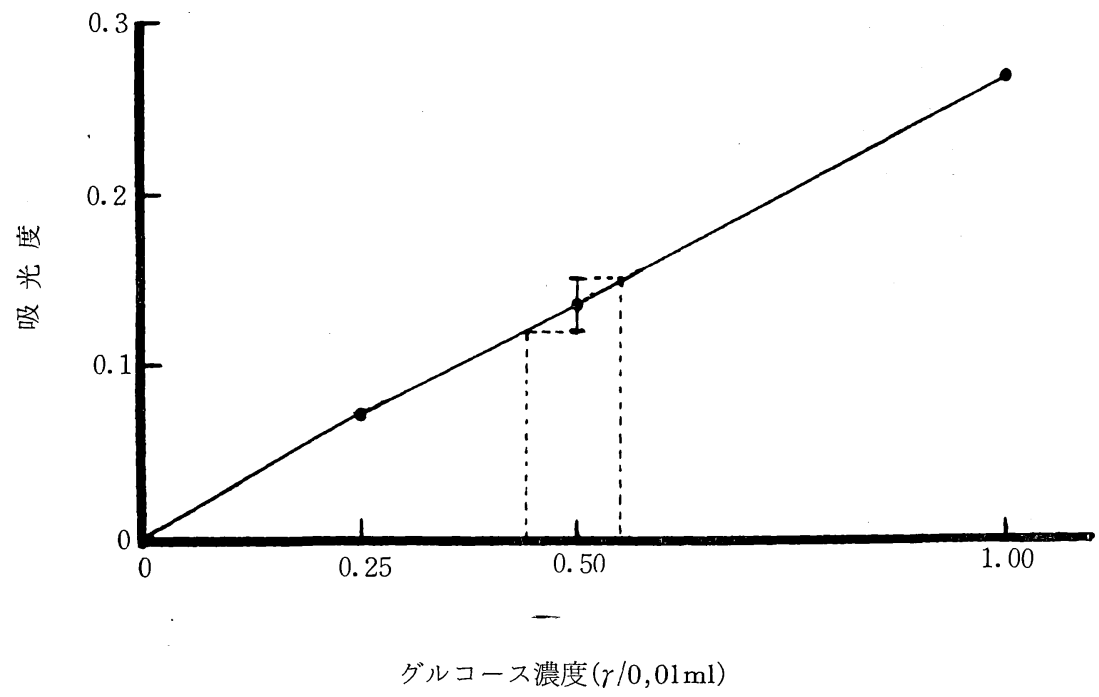


第 1 表

\begin{tabular}{|c|c|c|c|c|c|}
\hline & & 血 清 & 外リンパ & 脳水髄液 & 内リンパ \\
\hline グルコスタット & $\begin{array}{l}\text { 平均 值 } \\
\text { 裹却限界 }\end{array}$ & $\begin{array}{l}180.6 \\
118.6-242.6\end{array}$ & $\begin{array}{rc}125.2 & (13) \\
73.4 & -177.0\end{array}$ & $\begin{aligned} 113.5 & (10) \\
75.5 & -151.5\end{aligned}$ & $\begin{array}{lc}98.1 & (22) \\
36.6 & -159.6\end{array}$ \\
\hline アンスロン & $\begin{array}{l}\text { 平 均 值 } \\
\text { 裹却限界 }\end{array}$ & 209.7 & $\begin{array}{rc}148.3 & (8) \\
63.3 & -233.3\end{array}$ & 123.8 & 113.3 \\
\hline ソモギイ & 平均值 & & 202.6 & & \\
\hline
\end{tabular}

（）は測定検体数を示す

ついて同一実験条件でそれぞれの吸光度を測定して検 量曲線を描くと, 第 8 図にみる如く吸光度とグルコ一 ス濃度との間に高度の直線性が得られた（但し $0.50 \gamma /$ $0.01 \mathrm{~m} l$ 亿おける值は 10 測定值の平均值である).

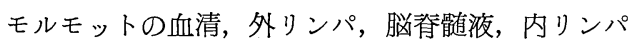
について各種方法で測定した結果を, 平均值および蓑 却限界*をもつて第 1 表に一括して示した. 表示の如 く, グルコース濃度は血清, 外リンパ, 脳春髄液, 内 リンパの順となつており，アンスロン值もてれと同じ 順位を示している. 外リンパについては 3 測定法によ る測定結果がともに揃つているので，てれらを比較し てみるとグルコスタット,アンスロン,ソモギィ・ネル ソンの順に測定值が高くなつている。脳脊蹎液, 内り ンパにおいても第 9 図の如くアンスロン值〉グルコス タット值の関係が同様にみられる。乙の差は外リンパ

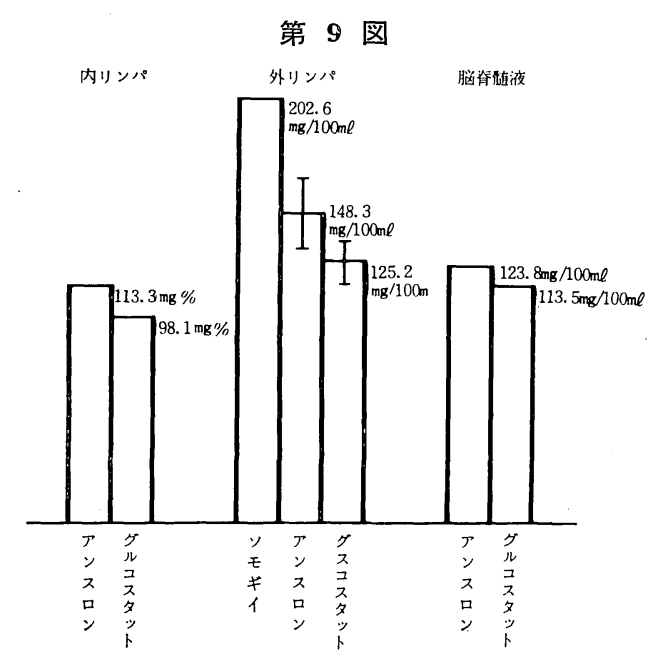

で最も大きく $23.1 \mathrm{mg} / 100 \mathrm{ml}(148.3 \mathrm{mg} / 100 \mathrm{ml}-125.2$ $\mathrm{mg} / 100 \mathrm{ml})$ であるが，てれは $5 \%$ 危険率では有意で なく $10 \%$ 危険率で始めて有意である。

グルコスタット法とアンスロン法の間で測定值分散 を比較すると, 外リンパの場合それぞれの標準偏差は 22.0および34.1であり, アンスロン法に比しグルコス タット法がより測定值変動が小であるととがわかる。

グルコスタット法で測定したグルコース量は先述の 如く血清>外リンパ>脳脊喵道液〉内リンパという関係 にあり(第10図)，そして血清と他の 3 者間には大き な濃度差がある。例えば血清と外リンパの間には 55.4 $\mathrm{mg} / 100 \mathrm{ml}$ の濃度差があり，てれは $1 \%$ 危険率におい ても有意である。**林対し, 外リンパ, 脳脊髄液, 内リンパの 3 者間ではグルコース濃度差は比較的小さ い. 即ち外りンパ・脳脊䯚液間の濃度差は $11.7 \mathrm{mg} / 100$

\section{第 10 図}

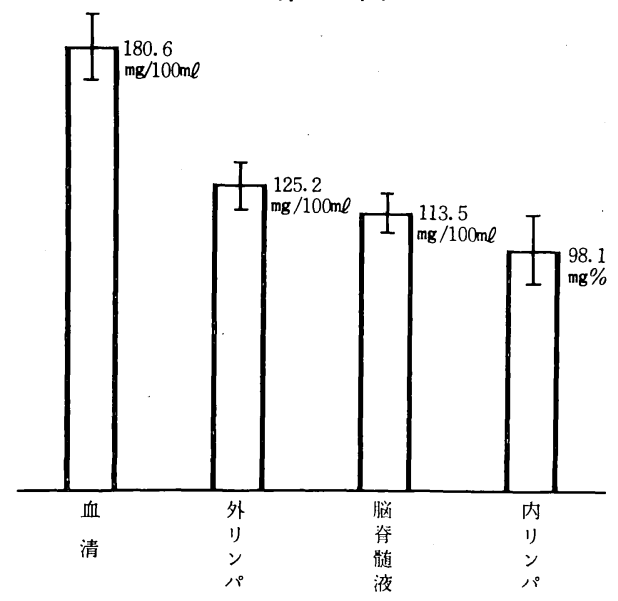

\footnotetext{
${ }^{*} \bar{x} \pm \mathrm{u} \sqrt{\mathrm{F} \alpha} \sqrt{1+\frac{1}{\mathrm{~N}}}, \quad \alpha=0.05$

** $\mathrm{t}=1.73$

$* * * \quad \mathrm{t}=5.63$
} 
$\mathrm{ml}$ であり，てれは $5 \%$ 危険率で有意でなく,* また 脳春霜液・内リンパ間の濃度差は $15.4 \mathrm{mg} / 100 \mathrm{ml}$ であ り（但し $1 \mathrm{mg} / 100 \mathrm{ml}$ と $1 \mathrm{mg} \%$ を近似的に等しいと考 える)，乙れも5\%危険率で有意でない**しかし外り ンパ・内リンパ間の濃度差は $27.1 \mathrm{mg} / 100 \mathrm{ml}$ であり, てれは1\%危険率で有意である。***

グルコスタット法で定量した場合の測定值の個体間 変動を血清, 外リンパ, 脳脊髄液, 内リンパの間で比 較してみると標準偏差は脳冷髄液（16.2），外リンパ (22.0)，血清（26.1），内リンパ（29.3）の順に大と なつている。これを変異係数 $\left(\frac{\text { 標準偏差 }}{\text { 平均值 }}\right)$ によつて 比較してみると，脳脊鹃液（0.143），血清 (0.145)， 外リンパ(0.176), 内リンパ（0.299）の順に大となつ ている.

\section{3) 考按}

グルコスタット法においてグルコスタットの反応時間 は原法 ${ }^{2122}$ 亿従い10分としたが，内耳液試料について も果しててれが適当であるか否かを検討しておく必要 があつた．第11図は外りンパ試料をグルコスタット法 で定量した場合に得たグルコスタットの反応曲線であ り，反応開始後10分に塩酸添加を行なわずにその後も 反応を続行せしめ，その間30分にわたつて反応の進行 を観察したものである.てれよりみると,グルコスタッ トの反応は10分以内において大きく進行し，その後は 緩慢な進行を辿る．従つて本実験でグルコスタットの 反応時間を10分に設定したことは適当と考えられる。

人の血糖值は Kingsley らの方法 ${ }^{27}$ )で測定した場合， 静脈血の值は 73〜95mg/100ml (全血) といわれる ${ }^{28}$ ). 種々の動物の血液グルコース濃度を文献上で拾つてみ

\section{第 11 図}

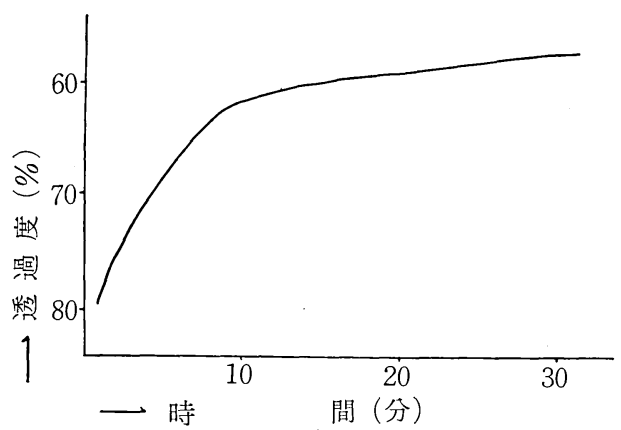

ると動物の種類によりかなり差異のあるととを知つ た．例えば猫 297 (血清) $\left.{ }^{29}\right), 乙 う し 118$ (血清) ${ }^{29}$ ), 犬 132 (血清) ${ }^{29}$ ), 山羊 83.5 (血漿) ${ }^{30}$ ), 猿148 (血清) ${ }^{29}$ ), 家鬼145 (血清 $)^{29}$ ), 羊80 (血清) ${ }^{29}$ ), 豚90 (血清) ${ }^{29}$ ), 蛙40.5 (血漿) ${ }^{31)}$ の如くである（単位は $\mathrm{mg} / 100 \mathrm{ml}$ ). モルモットの血清グルコース濃度についてはSomogyi $\left.{ }^{29}\right)$ が測定しており， $155 \mathrm{mg} / 100 \mathrm{ml}$ という值を得てい る. 本研究においては予めとの Somogyi の值を目安に して実験を行なつたが，モルモット血清のグルコスタ ット值は11匹についての平均值が $180.6 \mathrm{mg} / 100 \mathrm{ml}$ と なり Somogyi の值よりやや高い值が得られた。 アン スロン值は更に高く 8 匹のモルモットについての平均 值は $209.7 \mathrm{mg} / 100 \mathrm{ml}$ であつた. 何れにしてもモルモ ット血清のグルコースは，上述の各種動物の間では猫 に次いで高濃度であることがわかる。

モルモット脳脊髄液のグルコース量については未だ 報告をみない. しかしその他の多くの動物については 次のような值か蕔じられている。それらを上に記載し た血清グルコース濃度との比で示すと， 猫 $\left.{ }^{32}\right) 85 / 297$, 山羊 $\left.{ }^{32}\right) 71 / 83.5$ ，猿 ${ }^{32} 60 / 148$ ，家鬼 ${ }^{32)}(50 \sim 57) / 145$, 羊 $\left.{ }^{32}\right)(40 \sim 109) / 80$, 豚 $\left.{ }^{32}\right)(45 \sim 87) / 90$ の如くである(単 位は $\mathrm{mg} / 100 \mathrm{ml}$ ）。乙れよりみると，血清グルコース 濃度に対する脳脊髄液グルコース濃度の比は動物の種 類により異なり,猫の如く $1 / 3$ 以下のものもあれば, 山 羊のように 1 亿近いものもある。概して脳脊髄液グル コース濃度は血清のそれの $1 / 2$ ないし $2 / 3$ の附近にあ るので，本研究においてもてれを一応の目安として実 験に着手した．その結果モルモット弾春髄液のグルコ スタット值は10匹平均值が $113.5 \mathrm{mg} / 100 \mathrm{ml}$ であつた。 この值は先述した各種動物の值の何れよりも高い. な お血清に対する濃度比は $2 / 3$ 弱である。

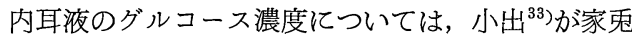
の外リンパについて測定を行なつているのみで，他に は人，動物を通じて研究がない，小出の正常家兔外り ンパについて 得た測定值は $100 \mathrm{mg} / \mathrm{d} \mathrm{l} \sim 110 \mathrm{mg} / \mathrm{d} I$ の 範囲にあつた，本実験において得られた結果は，モル モット13 匹についての平均值（グルコスタット法に よる）が $125.2 \mathrm{mg} / 100 \mathrm{ml}$ であつた。 との值は小出の 值よりやや高い值となつているが，乙れはモルモット の血清グルコースが家鬼のそれに比して高濃度である 事実と矛盾しない。

\footnotetext{
$* \mathrm{t}=1.41$

$* * \quad \mathrm{t}=1.55$

$* * * \quad \mathrm{t}=2.88$
} 
内リンパのグルコース 濃度は全く未知であつたの で，本実験によつて如何なる值が得られるかについて は当初より興味のもたれるところだつた。結局，内り ンパのグルコース量をミクロセルを利用するグルコス タット法で測定した場合， 22 耳についての平均值は $98.1 \mathrm{mg} \%$ という相対的に低い值が得られた。要する に先述の如く，外リンパ>脳脊髄液>内リンパという グルコース濃度の相互関係が明らかとなり，しかも外 リンパと内リンパの間にはグルコース濃度に有意差の あることが認められた。これらの事実は本実験で得ら れた新知見として特記し度い。

グルコース量を測定する方法として本実験において はグルコスタット法, アンスロン法, ソモギィ・ネル ソン法の 3 方法について検討を加えた。外リンパにつ いての定量実験の結果では，測定值はグルコスタット 值くアンスロン值くソモギィ值という関係にあるの で，今グルコスタット值が一般に考えられているよう に真のグルコース量を表わすものとすれば，外リンパ のアンスロン值およびソモギィ值は真のグルコース量 以上を表わしているととになる．外リンパにおいてア ンスロン值がグルコスタット值より僅かに大きいとと は, グルコース以外のヘキソース（単糖類, 寡糖類, 結 合糖）が低濃度ながら外リンパに存することを意味し ている．従つてアンスロン法は内耳液の場合はグルコ 一ス量よりむしろ総へキソース量について一つの目安 を与える方法として価值を有する．外リンパをソモギ ィ・ネルソン法で測定した場合は一段と高い值(202.6 $\mathrm{mg} / 100 \mathrm{ml})$ が得られている. この解釈としては，グ ルコース以外の還元物質が試料中に比較的多く含まれ ていること，本法は除蛋白操作を必要とするのでこの 操作中に定量上.誤差が大となること，等々が挙げら れよう。加様にして内耳液グルコースの定量において はてれら 3 方法のうち，グルコスタット法が最もその
方法として適しているという結論がなされる。一方測 定値分散の面でもアンスロン法に比しグルコスタット 法が分散は小であるので, 微量定量法としてグルコス タット法がより優れた再現性を有するものと看做し得 る.

本実験で得たアンスロン值は先に述べた如く，総へ キソース量を表わすものと考えてよいので, 今とのへ キソース総量を $100 \%$ とする時遊離グルコース(グルコ スタット值）の占める部分は第12図の如く示すととが できる. 本実験の結果ではこの部分は外リンパで84.4 \%, 内リンパで $86.5 \%$, 脳脊髄液で $91.7 \%$ となつてい る. 即ち, 遊離グルコース以外のヘキソースは外リン パで最もその含有比率が大 $(15.6 \%)$ で脳春髄液で最 も小 $(8.3 \%)$ であるととになる.

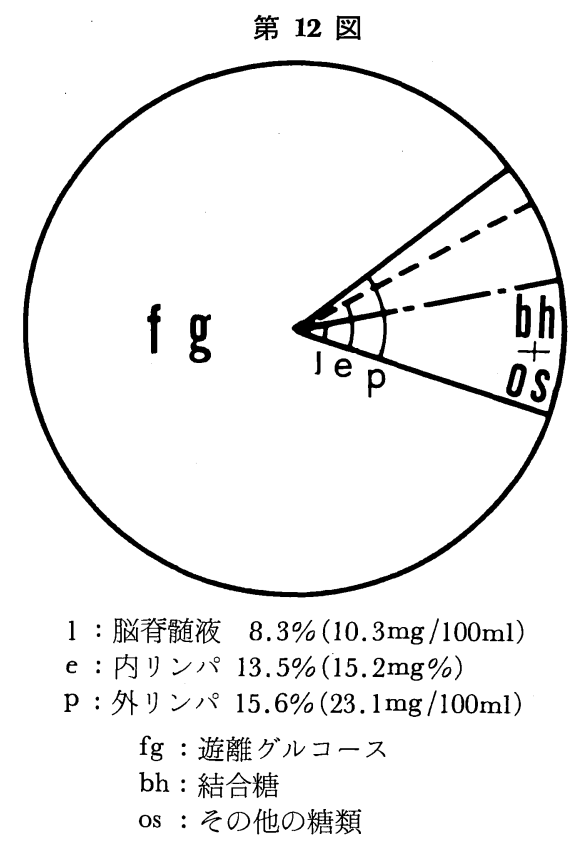

\section{〔IV】内耳液グルコース濃度の死後変化}

本実験においては動物を 3 群に分け，第 1 群では外 リンパと脳脊髄液のグルコース濃度を死後 5 時間迄観 察し, 第 2 群では内リンパのみを対象とし同樣の観察 を行ない, 第 3 群においては死後の CM について観察 した. かくして内耳液グルコース濃度の死後変化を分 析するとともに，乙れを死後の $\mathrm{CM}$ 出力の推移と対 比せしめ, GM2 の本態について若干の考察を加えた。

\section{1 ) 実験方法}

第 1 群においては同一動物より外リンパと脳脊髄液
の而者を採取し，グルコース濃度の測定は原則として 死後60分, 120分, 240分, 300分の各時点で行なつた. グルコースの定量は〔III]で既述のグルコスタット法 によつた。

第 2 群では第 1 群と同じ死後時点において内リンパ についてグルコース濃度の測定を行なつた．グルコー スの定量は〔III]で述べた内リンパ定量用のグルコス タット法によつた。両群とも気管閉塞によつて動物を 死に至らせた。 
第 3 群にわ゙いては，気管閉塞を行なつた動物につい てGMの振幅が如何に変化して行くかを, EKG の変化 と併わせて観察した，GM 誘導に際しては外リンパ採 取時と同様に動物を麻酔，固定した上，中耳骨胞を開 一ク円空を露出し，乙れに20ミクロン大の銀線を接着 壯た，電位の増幅ならびに電位の測定はシンクロスコ し（岩崎通信機製 SS-5102）によつた。本 CM 誘 導系によつて測定し得る最小の CM 振幅（peak to peak) は 4000cps 信号の場合, 約 $10 \mu \mathrm{V}$ であつた。
検查音は $4000 \mathrm{cps}$ 純音とし，音の強さは正常モルモ ットの平均 pseudo-threshold より約 $50 \mathrm{db}$ 上の一定 音圧に定めた。

\section{2) 実験結果}

第 1 群の実験結果を第13図と第14図に示す。第13図 において 1 点は 1 匹の動物の両耳合成外リンパのグル コース濃度を表わし，直線で結んだ 2 点は同一動物の 左右耳のグルコース濃度を表わしている. 図示の如く, 死後の外リンパグルコース濃度は時間の経過とともに

第 13 図

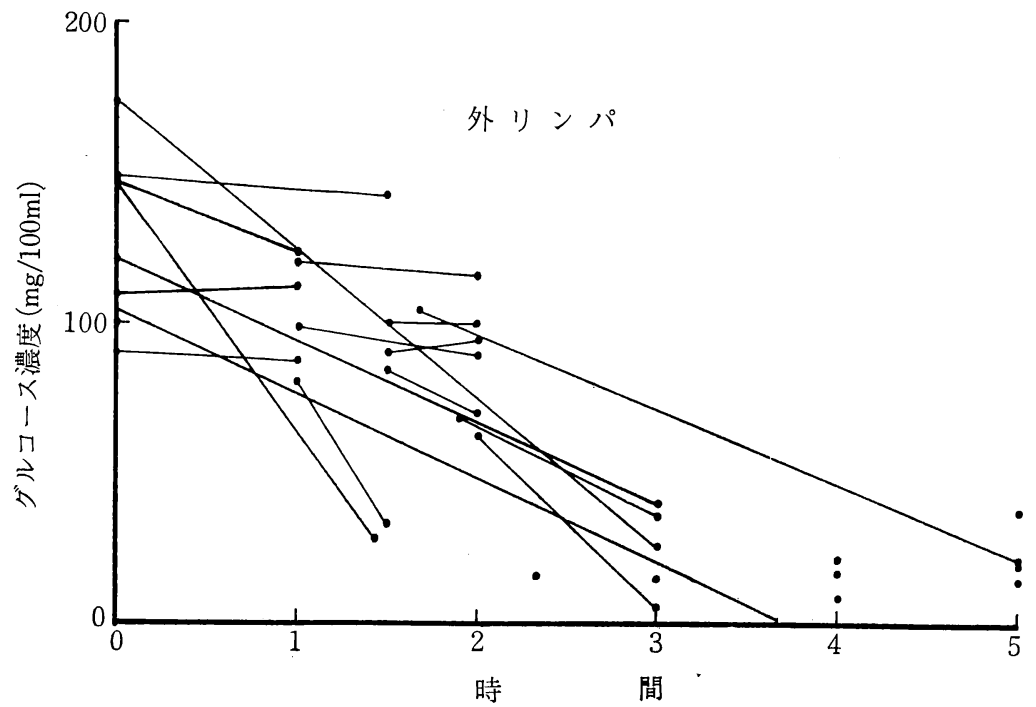

第豆14 図

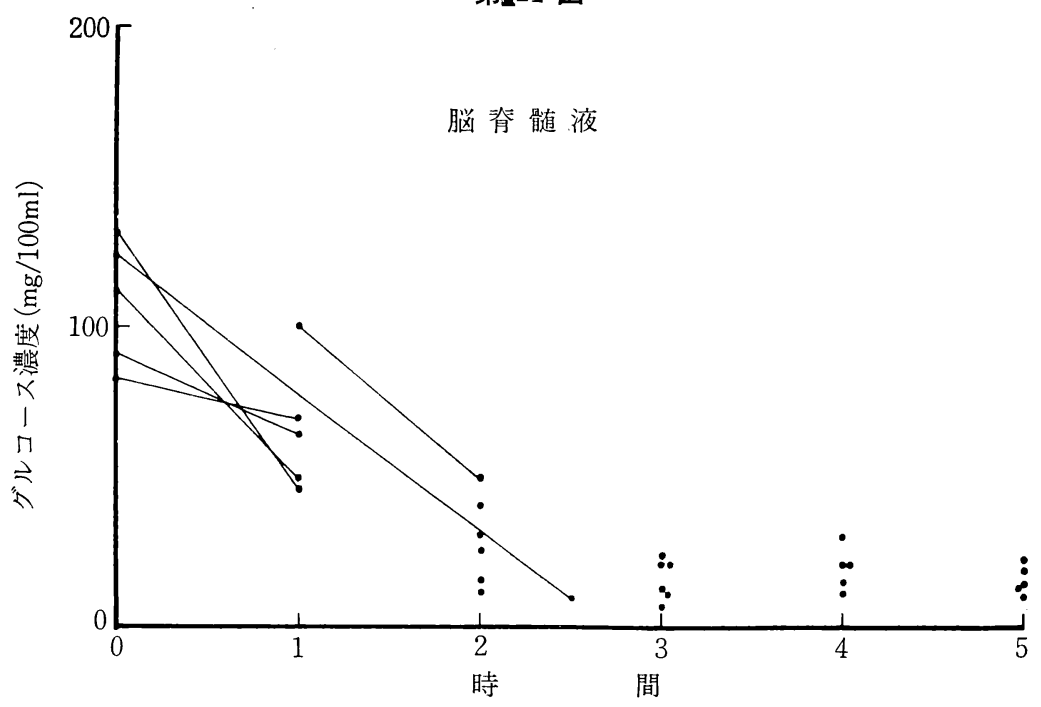


漸减して行つている. 即ち最初の 2 時間は緩徐な下降 を辿るが， 2 時間から 3 時間の間で比較的急速に低下 し, 以後 5 時間迄は同椂の低レベルで推移している. 第14図では，1 匹の動物より脳脊髄液を 1 回のみ採取 した場合はその測定值を 1 点で示し，同一動物より 2 回採取した場合は 2 時点での測定值を直線で結んで示 してある，乙の場合は死後 2 時間で既に低レベル（平 均約 $30 \mathrm{mg} / 100 \mathrm{ml}$ ） 亿達し, 外リンパの場合より下降 が速かである.

内リンパについての観察結果を第15図に示す，図に おいて 1 点は 1 耳の内リンパ試料についての測定值を 示し, 両耳について測定した場合は図示の如く両測定
值を直線で結んで示した．内リンパでは外リンパ，脳 脊葡液に較へ濃度低下が最も急速かつ著明である。即 ち死後 1 時間では全例とも測定值が $50 \mathrm{mg} \%$ 以下に達 しており， 2 時間では測定值平均は約 $10 \mathrm{mg} \%$ となり 5 時間迄てれと同様のレベルで推移している.

気管閉塞後の GM について 6 匹のモルモットで観 察された結果を第16図に示す。全例とも CM は窒息 後 4 分ないし 6 分迄に急速な低下を呈した。更に 1 時 間後迄は緩やかに低下して行くもの $(4$ 匹) と, 同レべ ルで移行するもの $(2$ 匹) とがあつた．窒息後 1 時間か ら 2 時間迄の間では 2 匹の 動物についての 観察で, CM は更に僅かながら低下して行く傾向をみるてとが

\section{第 15 図}

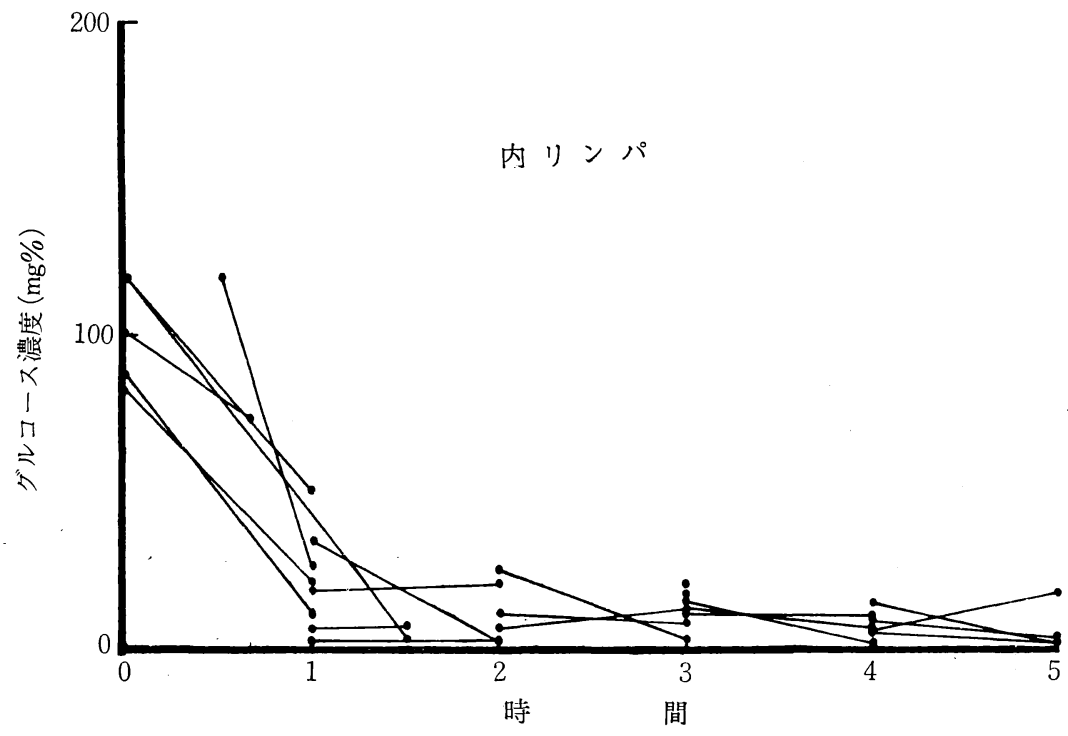

第 16 図

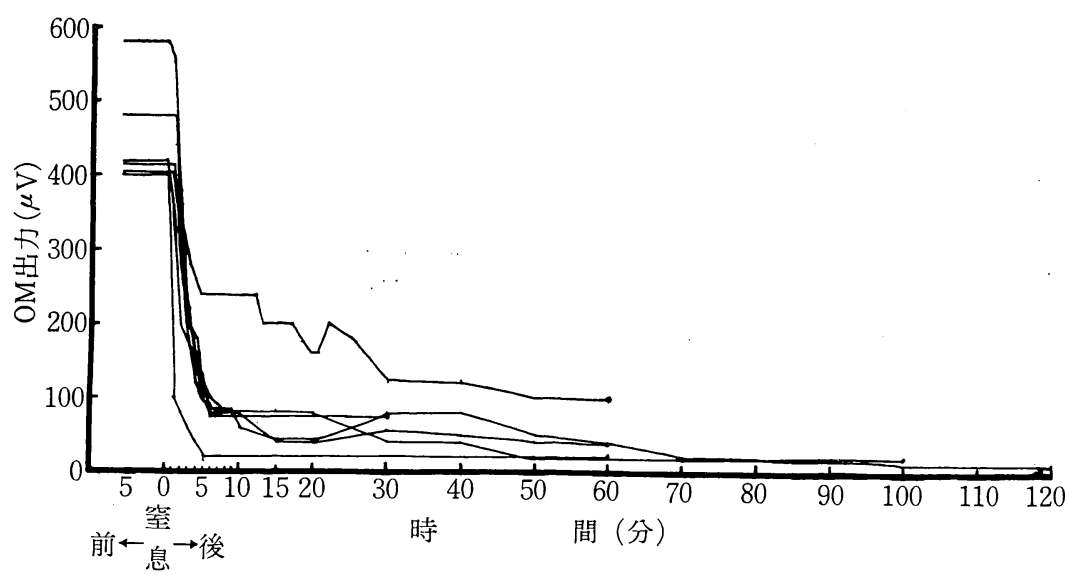


できる． 6 匹中 1 匹の動物では窒息後 5 時間にわたつ て観察記録した。本例では窒息後 2 時間から 5 時間迄 の間では $\mathrm{CM}$ 振幅は約 $10 \mu \mathrm{V}$ を保持し，時間的変動
は軽微であつた，GM2 の経過の上で特に注目される ことは，6匹中 3 匹の動物で窒息後20～30分の間で曲 線が反跳しているてとである. 第17図はその 1 例を示

第 17 図

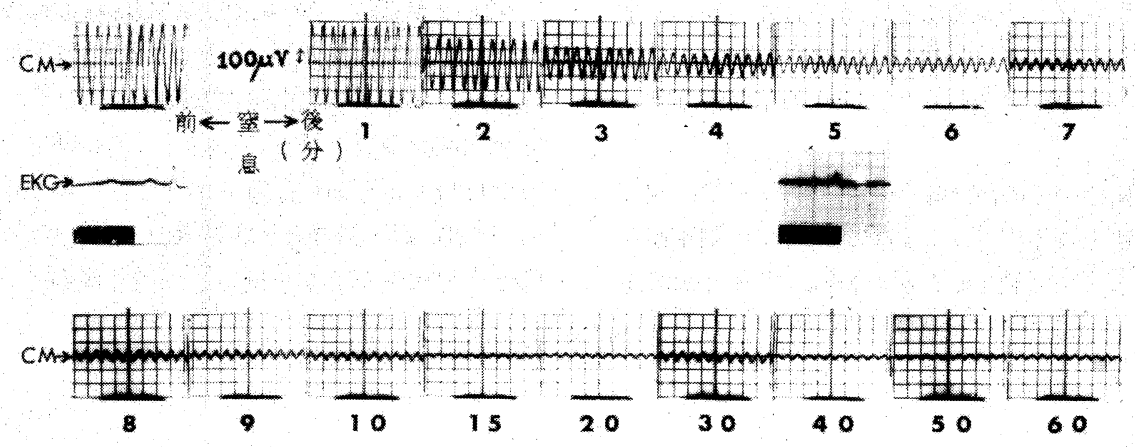

第 18 図
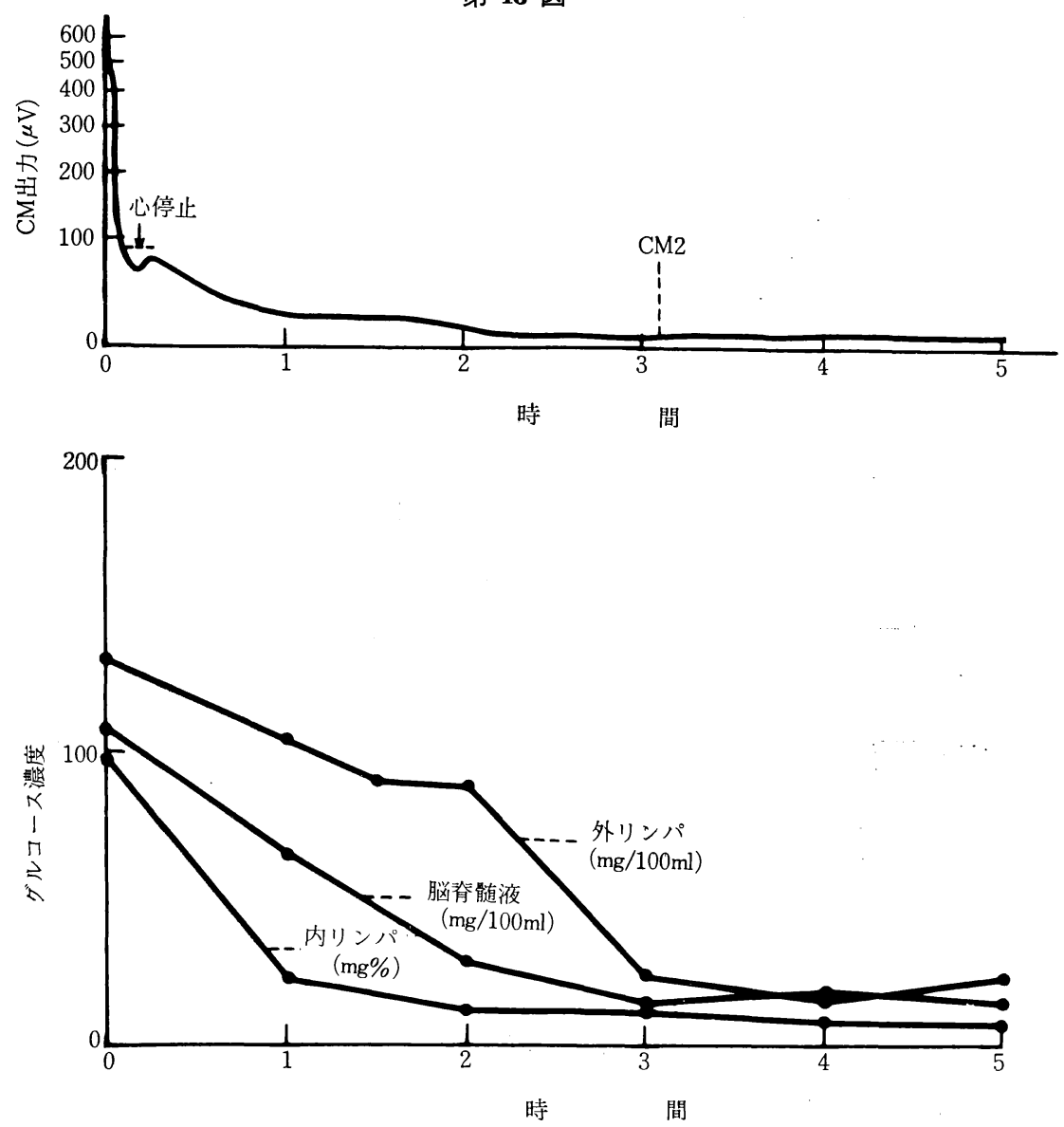
したものである.

本実験においてはCMと EKG の同時誘導を行ない， $\mathrm{CM}$ の変化を観察するとともに心停止時期の確認を企 図した，第17図にその実例を示す，心停止の時期は， QRS 波が図の如く微小となりしかも不規則散発的に 出現し始める時期をもつてその指標とした。 ての基準 で判定した結果によると動物 6 匹の心停止時期は気管 閉塞後 5 〜 13分の範囲にあつた.

\section{3) 考按}

蝸牛軟部組織とくに毛細胞では嫌気的条件下にわい ても解糖は進行し得るものと看做されている $\left.{ }^{8}\right)^{13}$ )。 と の点に関連して Koide $\left.~{ }^{13}\right)$ は迷路動脈を切断した場 合，外リンパのグルコース濃度が低下するととを報告 しているが，本研究においては動物の死後に外りンパ および内りンパのグルコース濃度が低下し，しかも内 リンパにおける低下がより急速であるととが確認され た。䤃素は生細胞住り生成されるが，その作用は細 胞とは独立であり，死細胞におても䤃素活性は失われ ない，従つて内りンパでより急速なグルコース濃度の 低下がみられるのは，嫌気的条件下のグルコース代謝 に関与する酵素系が，外リンパ腔周囲組織に比して， より高度に内リンパ腔周囲組織に分布するととを示唆 している，事実，嫌気的解糖において重要な役割をな す Lactate-dehydrogenase の活性は蝸牛では毛細胞, 聴神経終末, 血管条, 外ラセン溝に証明されており, 外リンパ腔に面した組織では少なくとも組織化学的方 法によつては本酵素の活性は認められていない8

CM の本態を追求する研究としては, Békésy の実 験 ${ }^{34}$ 方注目される。彼は猫の前庭階に小鉄球を入れラ イスネル氏膜に静置するようにし，てれに急激に磁力 在作用させ，鉄球をライスネル氏膜より引き揚げるこ とにより膜に衝激が加わるよう設置し，機械的刺激に よつて誘発される CM を正常時と低酸素時とにおいて 観察した。その結果，機械的エネルギーが電気的エネ ルギーへ忠実に変換されるととを否定した．とれに関

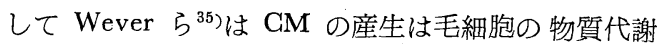
に基づく energy pool により支えられるとし, energy pool は毛細胞の分極であると考えた。しかし CM2 亿 ついてはこの考えを拡大するてとを避けている．

CM2 は CM のうち酸素によつて影響を受けない部 分として定義づけられているが，その本態に関して は，てれが何らかの物質代謝と共䡉しているものか, 或いは単に機械的エネルギーが電気的エネルギーへ変 換されたものであるかについて見解が分れている.
Wever ら $\left.{ }^{14}\right)$ はモルモットを使用七，死後，音の強さ が $20 \mathrm{db}$ 異なる 2 音を別々に左右の耳に与光， CM を 両耳より筍々に誘導しその振幅を経時的に記録した。 彼等は若し $\mathrm{CM} 2$ が蝸牛内細胞の生活反応であるとす れば，刺激音(この実験では検査音と刺激音を共用)の 強さが強大である程 CM2 の減少は著明になる筈だと の想定の下に， CM2 の時間曲線が刺激音の強さによ つて如何涼響されるかを観察した。气の結果刺激音 の強さによる影響はみられなかつたという。かくして 彼らは CM2 は機械的エネルギーが電気的エネルギー へ直接的に変換されたものであると推論した。

上記 Wever らの発表 ${ }^{14}$ 以外には， CM2 の本質論 亿触れる研究の報告は見当らず, 彼等の見解は追試, 実 証に至らず現在に及んでいる。 また CM2 の死後存続 時間についても確実な解答はなされていない. Wever らの実験 ${ }^{14}$ によると， CM2 は死後 5 時間迄は認めら れたが，24 時間後の時点では既に消失していたとい う.

本実験で得た CM および各種体液のグルコース濃 度についての観察結果を, 両者対比させて第18図に示 した. 図中上段の曲線は動物 6 匹についての GM2の

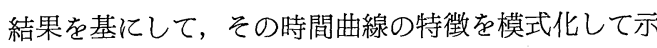
したものである，気管閉塞後直ちに始まる CM 出力 の急速な低下に後続して図示のような反跳が認められ ることについては，Wever らもこれを指摘しており earlier rebound と呼んでいる ${ }^{14}$. 彼等はまた死後 120 分前後においても late rebound なるものを認めたと いうが，本実験ではこれを確認できなかつた。

第18図下段は死後における各種体液のグルコース濃 度の時間曲線であり, 各時点にわける各液の測定值の 平均を結んだものである.

今上段と下段の両実験結果を対比し考察してみる そ，両者の間には一定の相関を見出すととはできな い，また，たとえ毛細胞が㥪気的解糖に要するグルコ 一スを Corti-lymph より摂取するとしても, Cortilymph へのグルコースの輸送機構が明らかにされて ない現在では, 内!ンパ或いは外りンパのうち何れの グルコース濃度が Corti-lymph のそれの指標となり 得るか決定し難いので，乙の観察結果より CM2 の本 態を迴つて皘極的な考察をなすととに躊躇せざるを得 ない，ただててでいえるてとは，内リンパおよび外り ンパの両内耳液で, グルコースが低濃度ながら含有さ れるような生化学的条件を蝸牛になお保持している期 間には， GM2 も低レベルながら産生され得る状態に 
あるということである.

\section{〔V〕綜括および希按}

本研究の目的は内耳液グルコースの定性・定量につ いて, その微量化学的方法を考案し, その検定された 方法をもつて現在なお未知の領域に富む内耳液化学組 成をグルコースに関して明らかにせんとしたものであ る.

予想されたように，内りンパ採取には技術上の困難 があり，先ずこれを克服する必要があつた．内リンパ 採取法としては，蝸牛管外側の骨壁に小孔を開き，乙 れより毛細管をラセン靱帯，血管条を貫通して内リン パ腔へ刺入する方法, 卵形囊内へ毛細管を刺入する方 法等があり，著者もてれらの方法を何回か試みてみ た. 2,3 の方法を変遷した後, 本研究では先述の如 く基底板より刺入する方法を採用した，本法は他に比 して一層確実であり，外リンパ混入の危惧もより少な く，優れた採取方法といえる．

外リンパグルコースのペーパークロマトグラフィー に関する実験では，試料を除蛋白せず直接濾紙につ け，フェノールまたはブタ・酢・水の展開溶媒で展開 し，アニリンフタル酸で発色すれば，グルコースの検 出は容易であるととがわかつた，但しての場合，グル コースの明瞭なスポットを得るには外リンパ 2 耳分 (約 $15 \mu l$ ) を必要としている.

内リンパについて同様のスポットを得るには，少な くとも約 $10 耳$ 分の内リンパ試料が必要と推計される. しかし10耳以上も内リンパを採取し集合してその中の グルコースを検出するという実験は既に内リンパ糖代 謝についての動的研究には実際的でなく，むしろ内リ ンパの化学分析を目的とするような場合においてその 意義を有するものといえよう。

外リンパグルコースのガスクロマトグラフィーに関 する実験では，試料を透析法または水酸化亜鉛法で除 蛋白し，その凍結乾燥試料を TMS 化した上ガスク

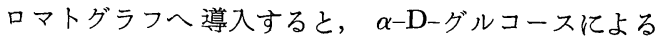
一つの波が観察された。乙の場合，明瞭な波形を得る には外リンパ1耳分（約 $7 \mu l ）$ のグルコースで充分で あることがわかつた。しかし除蛋白や TMS 化の操 作に際し試料の損失があるので，実際には外リンパ 3 耳分 $($ 約 $20 \mu l)$ の試料が必要となる.

ペーパークロマトグラフィーおよびガスクロマトグ ラフィーによる定性実験で得た知見は，外リンパの遊 離単糖類わよび賽糖類の大部分を遊離グルコースが占
めているととである。乙れは定量実験で総へキソース 量を代表するアンスロン值とグルコース量を表わすグ ルコスタット值の差が比較的 小である事実と一致す る.

内耳液グルコースのペーパークロマトグラフィー は, 今後放射性グルコースの追跡実験等において, 放 射性グルコースの同定を行なう場合に重要な手段とな る.ガスクロマトグラフィーは生体にグルコース以外 の単糖類を負荷し, 内耳液においてそのグルコースと の交互代謝を観察する実験等で，負荷糖類のグルコー スに対する含有比をみる場合に有用であろう。

内耳液グルコースの定量実験においては，グルコス タット法, アンスロン法, ソモギィ・ネルソン法の3方法 のうちで何れが最も微量定量法に適し，何れが最も真 のグルコース量を表わすかについて検討を行なつた。

これら 3 方法による測定值（平均值）を外リンパにつ いてみると，ソモギィ值 $(202.6 \mathrm{mg} / 100 \mathrm{ml})>$ アンス ロン值 $(148.3 \mathrm{mg} / 100 \mathrm{ml})>ク ゙ ル コ ス タ ッ ト$ 值 $(125.2$ $\mathrm{mg} / 100 \mathrm{ml})$ という関係がみられた。 アンスロン值と グルコスタット值の差は，外リンパの場合は $23.1 \mathrm{mg} /$ $100 \mathrm{ml}$, 内リンパの場合は $15.2 \mathrm{mg} \%$ である.アンス ロンはヘキソース一般と広く発色反応をおてす試薬 ${ }^{23}$ であるので，上記の如き差がみられるのは，外リンパ および内リンパに遊離グルコース以外のヘキソースが それぞれ $23.1 \mathrm{mg} / 100 \mathrm{ml}$ および $15.2 \mathrm{mg} \%$ 含有される ととを意味する，従つてか様な体液試料について真の グルコース量を測定する場合は，アンスロン法はその 方法として適当でないといわねばならない，しかし別 の見方をすれば，試料中の遊離グルコース以外のへキ ソース量を知る必要のある場合にはアンスロン法の登 上する機会といえる、ソモギィ・ネルソン法は血中の 真糖量を測定する方法として一般の臨床検查で使用さ れているが，本研究で外リンパ試料について測定した 場合は，グルコスタット值との間に大きな差（77.4 $\mathrm{mg} / 100 \mathrm{ml}$ ) がみられた。 との差が何に起因するかに ついては明らかでないが，先に述べた如く外リンパ試 料中にグルコース以外の還元性物質が多く含まれるて と，また本法は除蛋白操作を必要とするので，乙の操 作により測定䛊差が大きくなるとと等が考えられる. 結局ソモギィ・ネルソン法は定量操作が複雑であるこ と, 測定值が大きく変動し易いとと,しかも真のグルコ 
ース量より偏倚した值を示す傾向のあるとと等の欠点 から,内耳液グルコースの定量には適当とはいえない．

一方アンスロン法とグルコスタット法を，測定值分 散の点について比較すると, 外リンパについての測定 值の標準偏差はアンスロン法34.1, グルコスタット法 22.0であつた．乙れは微量定量法としてのグルコスタ ット法が測定の再現性において一段と優ることを意味 する。

先述の如く本研究で得られた一つの知見は, モルモ ットでは血清 $(180.6 \mathrm{mg} / 100 \mathrm{ml})>$ 外リンパ $(125.2$ $\mathrm{mg} / 100 \mathrm{ml})>$ 脳脊髄液 $(113.5 \mathrm{mg} / 100 \mathrm{ml})>$ 内リンパ $(98.1 \mathrm{mg} \%)$ というグルコース濃度の相互関係が存す るととである．内リンパのグルコースがか様に低濃度 であることは，内リンパにおけるグルコース代謝およ び血液・内リンパ間におけるグルコース輸送系が外り ンパにおけるそれに比較して何らかの差異を有するこ とを示唆しており興味がある。

グルコスタット法はその測定值分散が，アンスロン 法のそれに比し小であるととを述べたが，一般的には グルコスタット法といえどもその測定值標準偏差はな お大であると評価されねばならず，測定值分散が最小 である脳脊髄夜においてもその変異係数は $10 \%$ 以上と なつておる。乙れは一つは微量定量であるが故に測定 誤差が大となるためであり，一つは動物個体間にグル コース濃度の大きな変動があるためと考えられる．測 定誤差を小にするためには，微量定量手技に熟達する よう努める他, 定量用の器具や測定器機の改良, 開発 の方向へとも進まねばならない，動物の個体間変動を 少なくするためには，今後にその検討の余地が残され ていることとして，麻酔深度を全ての被検動物につい て一定状態におくこと，また空腹の条件を厳に一様に 揃えるとと等があると思われる，本研究を実施するに 当つては特に空腹の条件を揃えることに実際上の困難 を感じた。

内耳液採取に当つては常に血液の混入を避けるよう 努めねばならないが，てれを死後の動物について行な う場合はての危険性はなくなる。しかし死後内耳液で はグルコース濃度が漸次低下して行くことを本研究に より知つたので, 死後の内耳液試料をもつて生前のそ れに代えることは，少なくともグルコース定量におい ては無意味であるととがわかつた。

一般に個体の死後, 各種体液のグルコース濃度は時 間経過とともに低下するといわれており，人では屍体 の血液グルコース濃度を測定すれば死後時間の判定に
役立つと法医学領域ではいわれておる ${ }^{36}$ )。しかして本 研究により, 内耳液, 脳春髄液においても同様に死後 グルコース濃度の低下することか明らかにされた，更 に内リンパ，外リンパ,脳春䯙液の間では,内リンパで その低下が最も急速で, 外リンパで最も緩慢であるて とがわかつた。この所見は内リンパ腔の周囲組織に嫌 気的条件下のグルコース代謝に必要とされる酵素系が より多く分布しているととを意味するものである．と こで嫌気的解糖における乳酸産生に関与する Lactatedehydrogenase が毛細胞，聴神経終末，血管条，外ラ セン溝にその活性が証明され，外リンパ腔に面した組 織には証明されない事実 $\left.{ }^{8}\right)$ が興味深く思い出される。 内リンパ腔の体積は外リンパのそれに比し遙かに小で あるから，乙の種の酵素系が内リンパと外リンパの周 囲組織にたとえ同等に分布していたとしても，死後の グルコース濃度の 低下は内リンパにおいてより著明 である筈である．ここで好気的代謝に必要とされる Cytochrome-oxidase, Succinate-dehydrogenase, DPNH-dehydrogenase, TPNH-dehydrogenase 亿触 れておくと，先に述べた如くこの場合も内リンパ腔に 面した組織では血管条，外ラセン溝にその活性が証明 されるが，外リンパ腔に面した組織では証明されてい な( $\left.\left(^{8}\right)^{9}\right)^{10}$ )

CM2 についての観察結果は Wever らの実験結果 ${ }^{14)}$ と大きく異なるものではなかつた． 即ち気管閉塞後 CM の振幅は 4 分ないし 6 分迄に著明に減少し，生前 のレベルの約 $1 / 10$ となり，その後も 2 時間迄，漸次減 少の経過を辿つた１匹の動物についての観察結果で は， CM2 は死後 2 時間 以後も僅かな減少を示しな がら存続し，死後 5 時間においても約 $10 \mu \mathrm{V}$ の振幅 (peak to peak) が計測された。

GM2 は1941年 Wever らによつて GM のうちの酸 素に無関係な部分として命名されたものであるが，乙 の本態に関してはてれが蝸牛毛細胞の生活反応である か，或いは単に機械的エネルギーが蝸牛で電気的エネ ルギーへ変換されたものであるかについて従来実証が ない，本研究においては，若し CM2 が生活反応であ るとすれば，嫌気的解糖のエネルギーがその産生を支 えているという一つの可能性の上に立つて，死後の内 耳液グルコース濃度と CM2 についてそれぞれの時間 曲線をつくり，両者を対比してみた。その結果，確か に内リンパと外リンパにおいて，死後にグルコースが 漸次消失して行く状態を認めることができたが，果し てとれが GM2 産生のために消費されたか否かを検討 
するには本実験を更に解析的な方向へ深くおし進める 必要がある. 本研究の実験結果より許される限界を越 えて敢えて想像すれば, 内リンパでは死後 5 時間迄の 間, グルコース消失は死後 1 時間以内で最大であり, 一方 $\mathrm{CM} 2$ 死後 1 時間以内は比較的高い電位を維持 しているととより, 内リンパのグルコースが Cortilymph 几移動し，とてで毛細胞によつて消費 (CM2 の産生を支える嫌気的解糖のために）されているので はなからうかと考察される。ただ確言できることは，

\section{結}

GM2 が僅かながらも存続する期間は, 蝸牛では, 内 耳液に低濃度ながらグルコースが含有されているよう な生化学的環境が維持されていることである．何れに しても本研究认おいては， GM2の本態を廻つててれ を死後の内耳液グルコース濃度との関連において積極 的に論ずることはできなかつたが，得られた結果の箇 々が今後のこの種の研究において何らかの資料として 活用されれば著者は幸である。

内耳におけるグルコース代射を研究するに当つては, 内耳夜グルコースについての化学分析方法 を確立することが必須と考えられる。著者は内耳液中のグルコースについて定性・定量を可能にす るために，先ず微量化学的方法を開発し，次いでその方法によりモルモットの内耳液，脳脊髄液， 血清についてグルコースの検出および定量を行なつた。なお本研究に附随した実験として，死後の 内耳液グルコース濃度の時間的変化を CM2 の時間的変化との関連の下にモルモットで観察した.

以上の実験によつて導かれた結論は以下の如くである.

1）外リンパグルコースのペーパークロマトグラフィーにおいては, 試料を少なくとも 2 耳分（約 $15 \mu \mathrm{l})$ 採取し，乙れを直接濾紙につけてフェノールまたはブタノール・酢酸・水の展開溶媒で展開 し，アニリンフタル酸で発色すればグルコースの明膫なスポットが得られる.

2）外リンパグルコースのガスクロマトグラフィーにおいては，少なくとも試料を 3 耳分（約 20

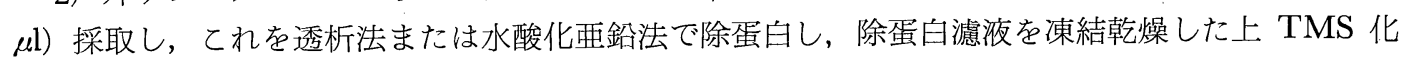

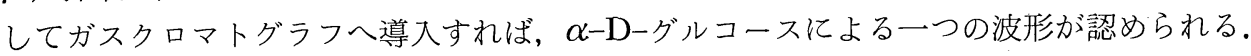

3）外リンパでは遊離糖の殆ど全てがグルコースである.

4）グルコスタット法は内リンパおよび外リンパのグルコース微量定量法に応用可能である.

5）内リンパと外リンパの間にはグルコース濃度に有意の差がある. 即ち内リンパでは, $98.1 \mathrm{mg}$ \%，外リンパでは $125.2 \mathrm{mg} / 100 \mathrm{ml}$ である.

6）グルコース量を表わすグルコスタット值とヘキソース量を代表するアンスロン值との間には, 内リンパで, $15.2 \mathrm{mg} \%$ ，外リンパで $23.1 \mathrm{mg} / 100 \mathrm{ml}$ の差があり，ての差は内リンパおよび外リン パに含まれる遊離ら゙ルコース以外のヘキソースの含有量に相当する。

7）動物の死後，内リンパ，外リンパ，脳脊髄液のグルコース濃度は漸次低下する，とくに内リ ンパでその低下が最も急速且つ著明であり，死後 1 時間では平均 $22 \mathrm{mg} \%$ となる.

8）動物を気管閉塞により窒息死させた場合，CM の振巾は気管閉塞後 4 分ないし 6 分迄々著明 に減小する，以後も漸次減小を続けるが，少なくとも気管閉塞後 5 時間迄は電位を計測し得る.

9）死後の内耳液グルコース濃度の時間曲線と CM2 の時間曲線との間には一定の相関は見出し 得ないが, 死後 5 時間以内では CM2 も存続し内耳液グルコースも低濃度ながら存在する.

本研究により得た知見のうち重要なものは, 内・外リンパ，脳脊髄液，血清の 4 者間におけるグ ルコースの濃度勾配様式を明らかにしたととであり，ての知見は内耳におけるグルコースの輸送機 構の解明の上に役立つものであろう.

本論文の内容は第 8 回日本オージロジー学会総会, 第 25 回近畿耳鼻咽喉科学会, 第11回日本内耳生化学研究 会, 第 21 回耳鼻咽喉科臨床会総会においてその一部を報告した。 


\section{文}

1) Smith, C.A., Lowry, O.H., and Wu, M.L. : Electrolytes of Labyrinthine Fluids. Laryngoscope (St. Louis) $64:$ 141, 1954.

2) Gitron, L., Exley, D., and Hallpike, C.S. : Labyrinthine Fluids. Brit. Med. J. 12 : 101, 1956.

3) Rauch, S., et Koestlin, A. : Aspects chimiques de 1'Endolymphe et de Ia Perilymphe. Pract. oto-rhino-laryng. (Basel) 20 : 287, 1958.

4) 三宅弘：内耳液の生化学について, 日耳鼻 63 : 増刊 2 号；618，（昭和35年，2月）

5) Smith, C.A., Lowry, O.H., and Wu, M.L. : Electrolytes of Endolymph and Perilymph. Science 116 : 529, 1952.

6) Makimoto, K., Takeda, T., Ibusuki, T., and Morimoto, M. : Mucopolysaccharide in Perilymph. Ann. Otol.(St. Louis) in Press

7) Silverstein, H. : Biochemical Studies of the Inner Ear Fluids in the Cat. Ann. Otol. (St. Louis) $75:$ 48, 1966.

8) Vosteen, K.H. : Die Lokalisation vershiedener Atmungsfermente in der Schnecke. Arch. Ohr.-, Nas.-u. Kehlk.-Heilk. 171 : 368, 1958.

9) Vosteen, K.H. : The Histochemistry of the Enzymes of Oxygen Metabolism in the Inner Ear. Laryngoscope (St. Louis) $70: 351,1960$.

10) Nomura, Y., and Károly Balogh, JR.:Localization of DPNH and TPNH Diaphorase Activity in the Cochlea by Various Histochemical Techniques. Laryngoscope 74 : 1351, 1964.

11）渡利千里，他：カナマイシンの内耳組織におよぼ す影響, Audiology 7:3；113，(昭和39年)

12) 半藤怜子 : コルチ氏器のカナマイシンに対する受 傷性に関する研究，耳鼻臨床 $57: 7 ； 428$,（昭和 39年, 7 月)

13) Koide, Y., Yoshida, M., and Konno, M. : The Effect of Cutting the Labyrinthine Artery on the Oxygen Tension in the Labyrinth. Ann. Otol. (St. Louis) 68 : 164, 1959.

14) Wever, E.G., Bray, C.B., and Lawrence, M. : Nature of Cochlear Activity after Death. Ann. Otol. (St. Louis) $50: 317,1941$.
献

15）阿武喜美子，瀬野信子 : 実験化学講座 23 生物化 学 1:382, 丸善 (東京), (昭和32年, 12月)

16）藤井暢三 : 生化学実験法一 (定量篇) 一, 14, 南山堂 (東京)，(昭和33年，6月）

17）金井泉：臨床検査法提要，VII-48, 金原（東京， 京都)，(昭和35年，5月）

18) Sweeley, C.C., Bentley, R., Makita, M., and Wells, W.W. : Gas-Liquid Chromatography of Trimethylsilyl Derivatives of Sugars and Related Substances. J. Am. Chem. Soc. 85 : 2497, 1963.

19) Itasaka, O. : Biochemistry of Shellfish Lipid. J. Biochem. 60 : 52, 1966.

20）佐竹一夫：クロマトグラフィー，114，共立出版 (東京)，(昭和 38 年，8 月）

21) Kingsley, G.R., and Getchell, G. : Direct Ultramicro Glucose Oxidase Method for Determination of Glucose in Biologic Fluids. Glin. Chem $6: 466,1960$.

22) Middleton, J.E., and Griffiths, W.J. : Rapid Colorimetric Micro-Method for Estimating Glucose in Blood and G.S.F. Using Glucose Oxidase. Brit. Med. J. 2 : 1525, 1957.

23）堀越弘毅：化学の領域増刊 34 生化学領域におけ る光電比色法各論 2, 36, 南江堂 (東京), (昭和 37年，11月）

24) Sattler, C., and Zerban, F.W. : Limitations of the Anthrone Test for Carbohydrates. J.A.C.S. 72 : 3814, 1950.

25) Somogyi, M. : Notes on Sugar Determination. J. Biol. Chem. 195 : 19, 1952.

26) Dreywood, R. : Qualitative Test for Carbohydrate Material. Ind. Eng. Chem., Anal. Ed. 18 : 499, 1946.

27) Kingsley, G.R., and Reinhold, J.G. : Determination of True Glucose in Blood. J. Lab. and Clin. Med. 34 : 713, 1949.

28）藤井暢三, 操坦道 : 臨床医学検查法一その手ほ どきから——，225，南山堂 (東京)，（昭和28年， 10月)

29) Somogyi, M. : The Distribution of Sugar and Rate of Glucolysis in the Blood of Some 
Mammals. J. Biol. Chem. 103 : 665, 1933.

30) Murty, V.N., and Kehar, N.D. : Blood of Domestic Animals. Ind. J. Physiol. Allied Sc. $5: 71,1951$.

31) Hashimoto, K., and Nukata, S. : Cardiac Metabolism(III). Fol. pharm. jap. $47: 9,1951$.

32) Jamieson, W.M., and Prain, J.H.: Unpublished, 1952.

33) Koide, Y. : Introductory Studies on the Ghemical-Physiology of the Labyrinth. Acta Me- dica et Biologica $6: 1,1958$.

34) Békésy, G. : DG Resting Potentials Inside the Cochlear Partition. J. Acoust. Soc. Amer. 24 : 72,1952

35) Wever, E.G., and Lawrence, M. : Physiological Acoustics. Page 326, Princeton University Press (New Jersey), 1954.

36) Thorsen, N. : Blutzuckeruntersuchungen an der Leiche. Z. Gericht. Med. 38 : 358, 1944.

〔抄 録〕

聴神経腫瘍に対する手術，特に呼吸盾環系症状の重要性について

\section{Acoustic Tumor Surgery The Significance of Vital Sign Changes.}

William E. Hitselberger, William F. House (Los Angeles)

Arch. Otolaryng. 84 : 255 260, 1966.

聴神経腫瘍の手術中に遭遇する幾つかの困難につい て述へている.これらの困難や術後の死亡, 機能障害は 前下小脳動脈およびその分枝が脳幹の重要な中枢を栄 養している事により理解される。本動脈の解剖, 本動 脈の開塞によつて起る血圧の変化に対する従来の知見 を述へた．著者らの 114 例の聴神経腫場手術の内 34 例 に術中呼吸循環系は重篤な変化を認めた。その内代表 5 例について詳細に報告した。 2 例は死亡てれらは全
剔出例， 4 例は亜全剔例で特にその内 3 例では術中血 圧，脈搏，呼吸の変動を来した時に術を打切つて事な きを待ている。他の 1 例は変化を認めた時に術を打切 り，2 年半後再発，再手術時に全剔が行なわれた。

腫煬の牽引, 機械の問題, 剝離の問題, 電気凝固, 麻醉, 術前の前下小脳動脈のレ線所見などについて簡 単に問頭点を述べている。

(柳原抄)

\section{聴覚時間因子刺激による下丘単一神経線維反応 \\ Responses of Units of the Inferior Colliculus to Time-varying Acoustic Stimuli}

Nelson P. G., Erulkar : S. D., and Bryan. J. S. (Philadelphia)

J. Neurophysiol. 24 : 5 ; 834 Sept. '66

音響刺激により誘発される聴覚路単一神経線維反応 の特徴に対し最近注目されて来ている。神経線維反応 には興舊性機構と抑制性機構の存在が明らかになつて いる.

著者らは猫を用い amplitude および frequencyの変 化した音響刺激を与え下丘より細胞外電位をとりその 相関関係を見た. その結果次の様な結論に達している。
(1) 神経反応は周波数に特異性をもつている.

(2) 下丘レベルにおいては興舊性 inputs と抑制性 inputs との間に相互作用があり，乙れら相互作用は更 に高次中枢で統轄されている，又著者らの方法がこの シナップス機構を機能的に解明するに役立つと推定し ている.

(吉岡抄) 